\title{
The lichens of Bolshoy Tuters Island (Tytärsaari), Leningrad Region, Russia
}

\section{Irina S. Stepanchikova ${ }^{1,2}$, Mikhail P. Andreev², Dmitry E. Himelbrant ${ }^{1,2}$, Jurga Motiejūnaitè $^{3}$, Ulf Schiefelbein ${ }^{4}$, Ludmila A. Konoreva ${ }^{2,5}$, Teuvo Ahti ${ }^{6}$}

${ }^{1}$ St. Petersburg State University (SPbSU), Universitetskaya emb. 7-9, 199034 St. Petersburg, Russia.

E-mails: stepa_ir@mail.ru,d_brant@mail.ru

${ }^{2}$ Laboratory of Lichenology and Bryology, Komarov Botanical Institute RAS, Professor Popov St. 2,

197376 St. Petersburg, Russia

${ }^{3}$ Laboratory of Mycology, Institute of Botany, Nature Research Centre, Žaliųjų Ežerų 49, LT-08406 Vilnius, Lithuania.

E-mail: jurga.motiejunaite@botanika.lt

${ }^{4}$ Blücherstrasse 71, D-18055 Rostock, Germany. E-mail: Ulf.Schiefelbein@gmx.de

${ }^{5}$ Polar-alpine Botanical Garden-Institute, 184250 Murmansk Region, Kirovsk. E-mail: ajdarzapov@yandex.ru

${ }^{6}$ Botanical Museum, Finnish Museum of Natural History, P.O. Box 7, FI-00014 University of Helsinki, Finland.

E-mail: Teuvo.Ahti@helsinki.fi

\begin{abstract}
The updated checklist of Tuters Island (Leningrad Region, Russia) is presented. Of 331 species of recognized biota, 314 species of lichens, 16 lichenicolous fungi and one non-lichenized saprobic fungus are reported from Tuters Island. Of them, 202 species are new to the study area. Aspicilia epiglypta, Fuscidea praeruptorum, Micarea byssacea and Sarcogyne hypophaeoides are reported for the first time for Russia, Roselliniella stereocaulorum - for European Russia, Aspicilia polychroma, Carbonea vorticosa, Cercidospora stereocaulorum, Cladonia ciliata f. flavicans, C. rangiformis, Parmelia ernstiae, Plectocarpon cf. encausticum and Roselliniella cladoniae - for North-Western European Russia; Bachmanniomyces uncialicola, Bacidina sulphurella, Micarea botryoides, Miriquidica griseoatra and Stereocaulon nanodes are new to the Leningrad Region.
\end{abstract}

Keywords: Gulf of Finland; Aspicilia epiglypta; Fuscidea praeruptorum; Micarea byssacea; Sarcogyne hypophaeoides

\section{INTRODUCTION}

Bolshoy Tuters (Tuters, Tytärsaari) is one of the westernmost Russian islands in the Gulf of Finland (Baltic Sea), belonging to Kingisepp District, Leningrad Region. Unlike the nearby Hogland Island (Gogland, Suursaari), lichens of Tuters remained almost unstudied until recently. Early lichenological exploration of Tuters is connected with Magnus Brenner who visited the area in 1868 and collected several specimens, which were afterwards identified by William Nylander. Brenner reported several species for Tuters in his monograph on the lichen flora of Hogland (Brenner, 1886): Cetraria odontella Ach., Peltigera malacea (Ach.) Fr., Peltigera polydactyla (Neck.) Hoffm. f. collina Ach., Ramalina cuspidata (Ach.) Nyl., and Stereocaulon tomentosum Fr. (all taxa are cited according Brenner's publication). Critical revision of Brenner's collection in Herbarium of the Botanical Museum, University of Helsinki (H) by Nadezhda M. Alexeeva, Teuvo Ahti and Dmitry E. Himelbrant allowed to reidentify some of them: the specimen previously identified as Cetraria odontella was C. muricata,
Ramalina cuspidata was understood by Brenner as a synonym of $R$. siliquosa (and the specimen belongs to $R$. siliquosa), the specimen published as Stereocaulon tomentosum appeared to be $S$. alpinum var. gracilentum. Several more species collected by Brenner from Tuters remained unpublished; altogether 14 species are known from Tuters from Brenner's collection.

After Brenner's visit, nobody studied lichens on Tuters until 1990's when the island was open for research for the first time after the World War II. In 1992-1993 few specimens were collected by botanists - Finnish (Pertti and Terho Uotila) and Russian (Natalia B. Balashova), some records were later published (Alexeeva, 2005). The first comprehensive inventory of the lichen flora of Tuters was started by Mikhail P. Andreev in 1994. As the result of these studies, a list of lichens of Tuters island comprising 120 species was presented (Andreev, 2002). In 2015, field studies of Tuters lichens were continued by Irina S. Stepanchikova in frame of the Complex Expedition "Gogland" of the Russian Geographi- 
cal Society. The present paper is the outcome of the expedition in 2015 and the revision of herbarium collections made since 1868 to 1994 .

\section{STUDY AREA}

Bolshoy Tuters is a remote island in Gulf of Finland (Baltic Sea), $40 \mathrm{~km}$ distant from the nearest (Estonian) shore. Despite its small size (ca. $3 \mathrm{~km}$ diam., area of ca. $8.3 \mathrm{~km}^{2}$ ), landscapes of Tuters are diverse and vary from large siliceous rocks in the western and northern parts to dunes on the eastern shore. The island is covered mostly with pine forests; spruce, small-leaved forests and bogs are also represented, black alder stands can be found along the shore, and wastelands surround the abandoned, and destroyed, only village of the island. In the northern part of the island comparatively low disturbed spruce forest is present. The flora of vascular plants of Tuters includes 513 species (Glazkova, 2001).

Tuters and the neighbouring islands were inhabited mostly by Finnish people since the Middle Ages to 1939 (ca. 500 people in 100 houses in 1939). The island belonged, in different periods, to Sweden, Russia, Finland and the
Soviet Union. During the World War II Tuters was occupied by the German army, the military base having up to 3000 soldiers in 1942-1944, and cannons, bombs etc. are still abundant on the island, some of them are already covered with lichens.

After the war and up to 1990's the island was closed for visitors. Due to its position, landscape and history, Tuters is a unique island area in the Leningrad Region with a comparatively well-preserved and rich lichen flora. Tuters Island together with other islands and the adjacent marine area are partly included in the projected Federal Nature Reserve (Zapovednik) "Ingermanlandsky", which hopefully will be organized in 2017.

\section{MATERIAL AND METHODS}

The material was collected on Tuters during field trips by: M. P. Andreev (1994), and I. Stepanchikova (2015). In the list of localities (Table 1) mostly Finnish names are given for capes, bays etc., because most of these geographical objects do not have Russian names; the location of studied sites is presented on Fig. 1.

Table 1. List of sampling locations in Leningrad Region, Kingisepp District, Tuters Island (Bolshoy Tuters, Tytärsaari) (geographical coordinates are given in spatial reference system WGS 1984; main collectors: MA - Mikhail P. Andreev, IS - Irina S. Stepanchikova)

\begin{tabular}{|c|c|c|c|}
\hline Locality & Description, geographical coordinates, biotope & Date & $\begin{array}{l}\text { Col- } \\
\text { lector }\end{array}$ \\
\hline $\mathrm{m} 1$ & $\begin{array}{l}\text { NW shore, NE of cape Romppiniemi, rocky beach “Vanhanpiian uuni”, [59 } 51^{\prime} 42 \text { "N, } \\
27^{\circ} 11^{\prime} 00^{\prime} \text { "E], siliceous rocks and boulders }\end{array}$ & 19.08.1994 & MA \\
\hline $\mathrm{m} 2$ & $\begin{array}{l}\text { N part, } 0.5 \mathrm{~km} \mathrm{SW} \text { of Severny cape (Tiukinniemi), 59 } 51^{\prime} 40^{\prime \prime} \mathrm{N}, 27^{\circ} 11^{\prime} 30^{\prime \prime} \mathrm{E} \text {, young } \\
\text { spruce forest }\end{array}$ & 18.08 .1994 & MA \\
\hline $\mathrm{m} 3$ & $\begin{array}{l}\left.\text { ny cape (Tiukinniemi), [59 } 51^{\prime} 55^{\prime \prime} \mathrm{N}, 27^{\circ} 11^{\prime} 45^{\prime \prime} \mathrm{E}\right] \text {, siliceous rocks and } \\
\text { e seashore }\end{array}$ & 17.0 & MA \\
\hline $\mathrm{m} 4$ & $\begin{array}{l}\text { rny cape (Tiukinniemi), near bay Paskalahti, [59 } 51^{\prime} 48^{\prime \prime} \mathrm{N} \text {, } \\
\text { h forest and shrubs }\end{array}$ & 17.0 & MA \\
\hline m5 & $\begin{array}{l}\left.\text { W shore, S of Vaskiniemi, [59 } 51^{\prime} 11^{\prime \prime} \mathrm{N}, 27^{\circ} 10^{\prime} 36^{\prime \prime} \mathrm{E}\right] \text {, siliceous rocks and boulders on } \\
\text { seashore }\end{array}$ & 13.08 & MA \\
\hline m6 & $\begin{array}{l}\left.\text { Central part, near the lighthouse (Tytärsaaren majakka), [59 } 51^{\prime} \mathrm{N}, 27^{\circ} 11^{\prime} \mathrm{E}\right] \text {, siliceous } \\
\text { rocks in pine forest }\end{array}$ & $\begin{array}{l}16.08 \\
20.08\end{array}$ & \\
\hline $\mathrm{m} 7$ & $\begin{array}{l}\left.\text { Central part, road from the lighthouse (Tytärsaaren majakka), [59 } 51^{\prime} \mathrm{N}, 27^{\circ} 11^{\prime} \mathrm{E}\right] \text {, spruce } \\
\text { forest }\end{array}$ & 20.08.1994 & MA \\
\hline $\mathrm{m} 8$ & $\begin{array}{l}\left.\text { E part, N part of the dunes (Lentokiekka), [59 } 51^{\prime} 00^{\prime \prime} \mathrm{N}, 27^{\circ} 13^{\prime} 30^{\prime \prime} \mathrm{E}\right] \text {, dunes with forest, } \\
\text { graminoid-moss-lichen communities }\end{array}$ & 14.08 .1994 & MA \\
\hline $\mathrm{m} 9$ & $\begin{array}{l}\text { E part, N part of the dunes (Lentokiekka), close to cape Teilonniemi, [59 } 51^{\circ} 00^{\prime \prime} \mathrm{N} \text {, } \\
\left.27^{\circ} 13^{\prime} 33^{\prime \prime} \mathrm{E}\right] \text {, mossy wasteland }\end{array}$ & 14.08 .1994 & MA \\
\hline $\mathrm{n} 10$ & $\begin{array}{l}\left.\text { SW shore, bay Umplahti, [59 } 50^{\prime} 35^{\prime \prime} \mathrm{N}, 27^{\circ} 10^{\prime} 40^{\prime \prime} \mathrm{E}\right] \text {, siliceous boulders along the forest } \\
\text { edge }\end{array}$ & 1994 & $\mathrm{vat}$ \\
\hline
\end{tabular}


Table 1 (continued)

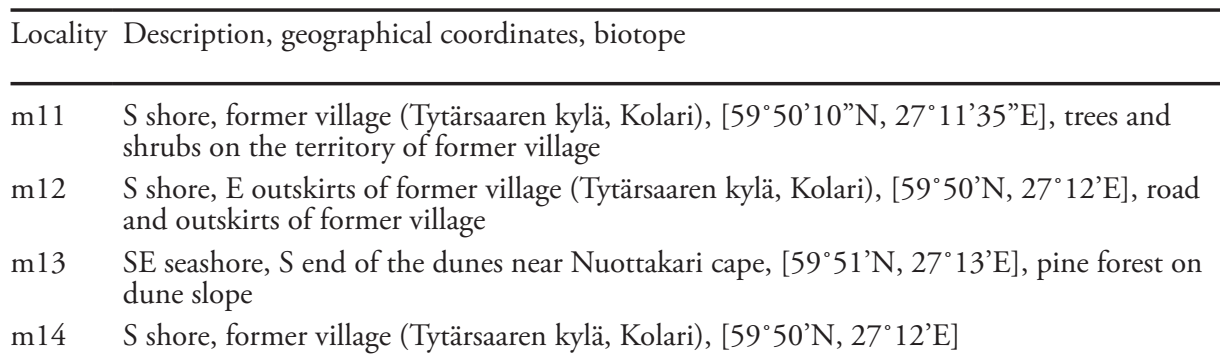

m15 E part of the dunes (Lentokiekka), [59 $51^{\prime} 00^{\prime \prime} \mathrm{N}, 27^{\circ} 13^{\prime} 30^{\prime \prime} \mathrm{E}$ ], sand field between seashore and high dunes

SW shore, S of ponds Römenlammet, $59^{\circ} 50^{\prime} 09^{\prime \prime} \mathrm{N}, 27^{\circ} 11^{\prime} 18^{\prime \prime} \mathrm{E}$, boulders of old quay SW shore, $\mathrm{N}$ of ponds Römenlammet, $59^{\circ} 50^{\prime} 13^{\prime \prime} \mathrm{N}, 27^{\circ} 11^{\prime} 17^{\prime \prime} \mathrm{E}$, young aspen stand on old concrete basement

SW shore, Umplahti, near pond Kärmeenlampi, 5950’26”N, $27^{\circ} 10^{\prime} 45^{\prime \prime} \mathrm{E}$, stony wasteland

$$
\text { SW shore, port area Vironsatama, 59 } 50^{\prime} 19^{\prime \prime} \mathrm{N}, 27^{\circ} 10^{\prime} 59^{\prime} \mathrm{E} \text {, pine forest with boulders }
$$
E part, N part of the dunes (Lentokiekka), 59 $50^{\prime} 56^{\prime \prime} \mathrm{N}, 27^{\circ} 13^{\prime} 11^{\prime \prime} \mathrm{E}$, old dunes covered with Racomitrium sp.

E part, N part of the dunes (Lentokiekka), 59 $50^{\prime} 53^{\prime \prime} \mathrm{N}, 27^{\circ} 13^{\prime} 13^{\prime \prime} \mathrm{E}$, vertical pine logs in dune (remnants of military constructions)

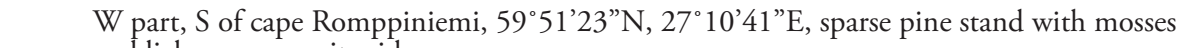
and lichens on granite ridge

W shore, $S$ of cape Romppiniemi, 59 $51^{\prime} 24^{\prime \prime} \mathrm{N}, 27^{\circ} 10^{\prime} 35^{\prime \prime} \mathrm{E}$, rocky seashore E part, N part of the dunes (Lentokiekka), 59 $51^{\prime} 01^{\prime \prime} \mathrm{N}, 27^{\circ} 13^{\prime} 20^{\prime \prime} \mathrm{E}$, sparse pine stand with mosses

E part, N part of the dunes (Lentokiekka), 59 $51^{\prime} 01^{\prime \prime} \mathrm{N}, 27^{\circ} 13^{\prime} 02^{\prime \prime} \mathrm{E}$, sparse pine stand with Racomitrium sp.

1 E part, $0.2 \mathrm{~km} \mathrm{~N}$ of the dune area, $59^{\circ} 51^{\prime} 10^{\prime \prime} \mathrm{N}, 27^{\circ} 13^{\prime} 01^{\prime \prime} \mathrm{E}$, spruce-pine forest with single aspens, with Oxalis acetosella L., Vaccinium myrtillus L., Maianthemum bifolium (L.) F. W. Schmidt and patches of Sphagnum sp.

E shore opposite to the N part of the dunes (Lentokiekka), 59 $51^{\prime} 03^{\prime \prime} \mathrm{N}, 27^{\circ} 13^{\prime} 32^{\prime \prime} \mathrm{E}$, seashore pine forest with boulders, near fishermen camp

Date

Collector

19.08.1994 MA

20.08.1994 MA

16.08.1994, MA

20.08.1994

18.06.1992 Pertti $\&$

Terho

Uotila

18.06.1992 Pertti \&

Terho

Uotila

28.05.2015 IS

28.05.2015 IS

28.05.2015 IS

28.05.2015 IS

29.05 .2015 IS

29.05.2015 IS

30.05 .2015 IS

30.05 .2015 IS

31.05.2015 IS

31.05 .2015 IS

31.05 .2015 IS

31.05.2015 IS

01.06 .2015 IS seashore

N part, $0.3 \mathrm{~km} \mathrm{SE}$ of Severny cape (Tiukinniemi), 59 $51^{\prime} 51^{\prime \prime} \mathrm{N}, 27^{\circ} 11^{\prime} 53^{\prime \prime} \mathrm{E}$, spruce forest with single aspens, with Vaccinium myrtillus, Maianthemum bifolium and green mosses

01.06 .2015 IS

01.06 .2015 IS boulders, Rubus idaeus L. and graminoids

E part, lowland Tuomäensuo E of the dune area, 59 $50^{\prime} 49^{\prime \prime} \mathrm{N}, 27^{\circ} 12^{\prime} 52^{\prime \prime} \mathrm{E}$, spruce forest with Vaccinium myrtillus and green mosses

02.06 .2015 IS

02.06.2015 IS Eriophorum vaginatum L., Calluna vulgaris (L.) Hull and Sphagnum spp.

W part, ca. $0.4 \mathrm{~km} \mathrm{NE}$ of bay Vaskilahti, rock Luöppärkallio, $59^{\circ} 51^{\prime} 11^{\prime \prime} \mathrm{N}, 27^{\circ} 10^{\prime} 58^{\prime \prime} \mathrm{E}$, sparse pine forest with spruce, lichens and mosses, on granite ridge

03.06 .2015 IS W part, bay Takirästelinlahti, $59^{\circ} 50^{\prime} 50^{\prime \prime} \mathrm{N}, 27^{\circ} 10^{\prime} 35^{\prime} \mathrm{E}$, aspen stand with pine and spruce on place of old house 
Table 1 (continued)

Locality Description, geographical coordinates, biotope

Date

Col-

lector

a1 S part, N vicinities of the former village (Tytärsaaren kylä, Kolari), 5950’30”N,

28.05.2015 IS

$27^{\circ} 11^{\prime} 25^{\prime \prime} \mathrm{E}$, spruce forest with Vaccinium mytrillus and green mosses

a2 E part, $S$ end of the dunes, $0.4 \mathrm{~km} \mathrm{~W}$ of cape Tuomäenniemi, $59^{\circ} 50^{\prime} 46^{\prime \prime} \mathrm{N}, 27^{\circ} 13^{\prime} 16^{\prime \prime} \mathrm{E}$, lichen community on sandy soil near the dune on margin of pine forest

a3 E shore, $\mathrm{S}$ of dunes near Nuottakari cape, $59^{\circ} 50^{\prime} 41^{\prime \prime} \mathrm{N}, 27^{\circ} 13^{\prime} 11^{\prime \prime} \mathrm{E}$, pine forest with lichens

a4 E shore, $S$ of dunes near Nuottakari cape, $59^{\circ} 50^{\prime} 40^{\prime \prime} \mathrm{N}, 27^{\circ} 13^{\prime} 07^{\prime \prime} \mathrm{E}$, pine forest with lichens

S shore, cape Ruuhainniemi, $59^{\circ} 50^{\prime} 22^{\prime \prime} \mathrm{N}, 27^{\circ} 12^{\prime} 26^{\prime \prime} \mathrm{E}$, small glade in pine forest with

29.05.2015 IS

29.05.2015 IS

29.05.2015 IS lichens

$\mathrm{S}$ shore, E of cape Lommosniemi, 59 $50^{\prime} 10^{\prime \prime} \mathrm{N}, 27^{\circ} 11^{\prime} 56^{\prime} \mathrm{E}$, old Finnish village, wasteland W part, $0.4 \mathrm{~km} \mathrm{NE}$ of bay Vaskilahti, rock Luöppärkallio, 59 51'09”N, $27^{\circ} 11^{\prime} 02^{\prime \prime} \mathrm{E}$, small tall-moss swamp in lowland between rocks, with small rocky outcrops

W part, $0.3 \mathrm{~km}$ NE of bay Vaskilahti, rock Luöppärkallio, 59 $51^{\prime} 14^{\prime \prime} \mathrm{N}, 27^{\circ} 10^{\prime} 53^{\prime \prime} \mathrm{E}$, pine forest with lichens and green mosses on granite ridge

W part, SE of cape Romppiniemi, 59 $51^{\prime} 21^{\prime \prime} \mathrm{N}, 27^{\circ} 10^{\prime} 49^{\prime \prime} \mathrm{E}$, pine forest with lichens and green mosses on granite ridge

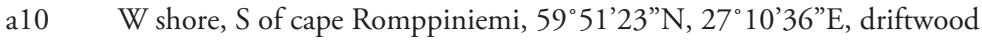

29.05.2015 IS

29.05.2015 IS

30.05.2015 IS

30.05 .2015 IS

30.05.2015 IS

30.05.2015 IS

a11

NW shore, S of cape Romppiniemi, 59 $51^{\prime} 33^{\prime \prime} \mathrm{N}, 27^{\circ} 10^{\prime} 37^{\prime \prime} \mathrm{E}$, seashore rocks

30.05 .2015 IS

a12

NW part, along rocky beach "Vanhanpiian uuni", 59 $51^{\prime} 36^{\prime} \mathrm{N}, 27^{\circ} 10^{\prime} 54$ ” E, pine forest on granite ridge

a13 NW part, ca. $0.3 \mathrm{~km} \mathrm{SE}$ of cape Romppiniemi, 59 51'31”N, 27¹0'58”E, pine forest on granite ridge

a14 E shore opposite to the N part of the dune area, Teilonniemi cape, $59^{\circ} 50^{\prime} 57^{\prime \prime} \mathrm{N}$,

$27^{\circ} 13^{\prime} 39^{\prime \prime} \mathrm{E}$, sandy seashore

a15 E shore opposite to the $\mathrm{N}$ part of the dune area, Teilonniemi cape, $59^{\circ} 50^{\prime} 54^{\prime \prime} \mathrm{N}$, $27^{\circ} 13^{\prime} 37^{\prime \prime} \mathrm{E}$, pine forest with lichens on sand

a16 E shore opposite to the $\mathrm{N}$ part of the dune area, $\mathrm{N}$ of cape Teilonniemi, 59 $51^{\prime} 05^{\prime \prime} \mathrm{N}$, $27^{\circ} 13^{\prime} 32^{\prime \prime} \mathrm{E}$, pine forest with lichens on sand

a17 E part, lowland Tuomäensuo E of the dune area, $59^{\circ} 50^{\prime} 54^{\prime \prime} \mathrm{N}, 27^{\circ} 13^{\prime} 01^{\prime \prime} \mathrm{E}$, pine forest with green mosses near the dune

NW part, $0.5 \mathrm{~km}$ SW of Severny cape (Tiukinniemi), 5951'40”N, 27¹1'24”E, spruce forest with Vaccinium myrtillus and Sphagnum spp.

30.05 .2015 IS

30.05 .2015 IS

31.05.2015 IS

31.05 .2015 IS

31.05.2015 IS

31.05.2015 IS

01.06 .2015 IS

N shore, cape Kuokkaniemi 59 51'56”N, 27 11'26”E, driftwood and remnants of building

01.06 .2015 IS

a20

$\mathrm{N}$ part, near cape Kuokkaniemi, 59 $51^{\prime} 54^{\prime} \mathrm{N}, 27^{\circ} 11^{\prime} 30^{\prime} \mathrm{E}$, remnants of German cannon in spruce forest

N shore, Severny cape (Tiukinniemi), 59 51'57”N, 27¹1'44”E, remnants of German army machine in seashore forest

NE shore, $0.5 \mathrm{~km}$ E to Severny cape (Tiukinniemi), near bay Paskalahti, 59 $51^{\prime} 44^{\prime \prime} \mathrm{N}$, $27^{\circ} 12^{\prime} 29^{\prime \prime}$, black alder stand in a bay

01.06 .2015 IS

$\mathrm{S}$ part, ca. $0.5 \mathrm{~km} \mathrm{NE}$ of the cemetery, 59 $50^{\prime} 28^{\prime \prime} \mathrm{N}, 27^{\circ} 12^{\prime} 23^{\prime \prime} \mathrm{E}$, remnants of barbed wire

E part, Lentohiekka (N part of the dunes), 59 $51^{\prime} 05^{\prime \prime} \mathrm{N}, 27^{\circ} 13^{\prime} 16^{\prime \prime} \mathrm{E}$, top of sandy dune

01.06.2015 IS

E part, $\mathrm{N}$ border of the dune area, near the seashore, 59 $51^{\prime} 12^{\prime \prime} \mathrm{N}, 27^{\circ} 13^{\prime} 19^{\prime \prime} \mathrm{E}$, group of black alder in spruce forest near the dune

01.06.2015 IS

02.06.2015 IS

02.06 .2015 IS

02.06 .2015 IS

02.06 .2015 IS

E part, $0.2 \mathrm{~km} \mathrm{~N}$ of the dune area, near the seashore, 59 $51^{\prime} 17^{\prime \prime} \mathrm{N}, 27^{\circ} 13^{\prime} 17^{\prime \prime} \mathrm{E}$, spruce for-

02.06 .2015 IS est with black alder near the seashore, with Oxalis acetosella, Vaccinium myrtillus and green mosses 
Table 1 (continued)

Locality Description, geographical coordinates, biotope

Date

Col-

lector

a29

Central part, bog Estersuo, 59 $51^{\prime} 06^{\prime \prime} \mathrm{N}, 27^{\circ} 11^{\prime} 08^{\prime \prime} \mathrm{E}$, group of trees and shrubs on a small

03.06.2015 IS

island in transitional swamp

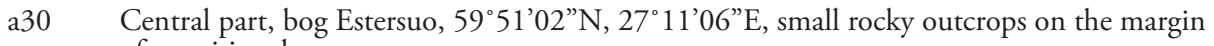
of transitional swamp

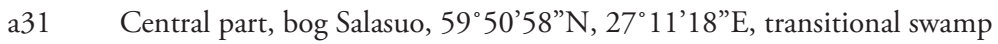

03.06.2015 IS

a32

Central part, $0.3 \mathrm{~km} \mathrm{SE}$ of bog Salasuo, 59 $50^{\prime} 51^{\prime \prime} \mathrm{N}, 27^{\circ} 11^{\prime} 41^{\prime \prime E}$, remnants of German ammunition depot in young pine forest

a33 Central part, $0.2 \mathrm{~km}$ E of bog Salasuo, 59 $50^{\prime} 55^{\prime \prime} \mathrm{N}, 27^{\circ} 11^{\prime} 35^{\prime \prime} \mathrm{E}$, pine forest with Vaccinium myrtillus, green mosses and Calluna vulgaris

03.06.2015 IS

03.06.2015 IS

03.06 .2015 IS

a34 Central part, $0.5 \mathrm{~km} \mathrm{SE}$ of bog Salasuo, ca. $0.5 \mathrm{~km} \mathrm{~N}$ of the former village, $59^{\circ} 50^{\prime} 47^{\prime \prime} \mathrm{N}$, $27^{\circ} 11^{\prime} 50^{\prime \prime} \mathrm{E}$, pine forest with Vaccinium myrtillus and green mosses, with sparse snags

a35 Central part, ca. $0.9 \mathrm{~km} \mathrm{~N}$ of the cemetery, $59^{\circ} 50^{\prime} 43^{\prime \prime} \mathrm{N}, 27^{\circ} 12^{\prime} 02^{\prime \prime} \mathrm{E}$, spruce forest with Vaccinium myrtillus and green mosses

$\mathrm{S}$ part, ca. $0.5 \mathrm{~km} \mathrm{NE}$ of the cemetery, $59^{\circ} 50^{\prime} 28^{\prime \prime} \mathrm{N}, 27^{\circ} 12^{\prime} 17^{\prime \prime} \mathrm{E}$, aspen forest with mixed herbs

03.06.2015 IS

03.06.2015 IS

03.06.2015 IS

a37 W part, E of cape Levitniemi, 59 $50^{\circ} 42^{\prime \prime} \mathrm{N}, 27^{\circ} 11^{\prime} 02^{\prime \prime} \mathrm{E}$, pine forest with lichens and green mosses on granite ridge

a38 W part, E of cape Levitniemi, 59 $50^{\circ} 43^{\prime \prime} \mathrm{N}, 27^{\circ} 10^{\prime} 42^{\prime \prime} \mathrm{E}$, pine forest with lichens and green mosses on granite ridge

a39 W shore, between capes Levitniemi and Takirästelinniemi, $59^{\circ} 50^{\prime} 45^{\prime \prime} \mathrm{N}, 27^{\circ} 10^{\prime} 37^{\prime \prime} \mathrm{E}$, spreaded boulders

a40 W part, between capes Levitniemi and Takirästelinniemi, $59^{\circ} 50^{\prime} 47^{\prime \prime} \mathrm{N}, 27^{\circ} 10^{\prime} 35^{\prime \prime} \mathrm{E}$, rocky outcrop

a41 W shore, bay Vaskilahti, 59 $51^{\prime} 09^{\prime \prime} \mathrm{N}, 27^{\circ} 10^{\prime} 33^{\prime \prime} \mathrm{E}$, internal surface of seashore rocks

a42 W shore, $\mathrm{N}$ of bay Vaskilahti, $59^{\circ} 51^{\prime} 14^{\prime \prime} \mathrm{N}, 27^{\circ} 10^{\prime} 34^{\prime \prime} \mathrm{E}$, rocks

a43 W shore, $\mathrm{N}$ of bay Vaskilahti, $59^{\circ} 51^{\prime} 15^{\prime \prime} \mathrm{N}, 27^{\circ} 10^{\prime} 34^{\prime \prime} \mathrm{E}$, rocks and old concrete

a44 W shore $\mathrm{N}$ of bay Vaskilahti S of cape Romppiniemi, 59 $51^{\prime} 20^{\prime \prime} \mathrm{N}, 27^{\circ} 10^{\prime} 37^{\prime \prime} \mathrm{E}$, granite ridge, soil in crevices

04.06 .2015 IS

04.06 .2015 IS

04.06 .2015 IS

04.06 .2015 IS

04.06 .2015 IS

04.06 .2015 IS

04.06 .2015 IS

04.06 .2015 IS

a 45 W part, $70 \mathrm{~m}$ of the seashore, SE of cape Romppiniemi, 59 $51^{\prime} 22^{\prime \prime} \mathrm{N}, 27^{\circ} 10^{\prime} 40^{\prime \prime} \mathrm{E}$, granite ridge, deep crevice

a46 W part, $70 \mathrm{~m}$ of the seashore, SE of cape Romppiniemi, 59 $51^{\prime} 24^{\prime \prime} \mathrm{N}, 27^{\circ} 10^{\prime} 39^{\prime \prime} \mathrm{E}$, old

04.06 .2015 IS spruce between rocks

a47 W part, seashore S of cape Romppiniemi, 59 $51^{\prime} 29^{\prime \prime} \mathrm{N}, 27^{\circ} 10^{\prime} 39^{\prime \prime} \mathrm{E}$, granite ridge surrounded by pine forest

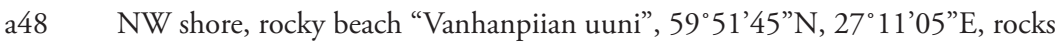

04.06 .2015 IS

04.06 .2015 IS

04.06 .2015 IS

04.06 .2015 IS

forest with Vaccinium myrtillus and green mosses

a50 NW part, SE of the rocky beach "Vanhanpiian uuni”, 59 $51^{\prime} 31^{\prime \prime} \mathrm{N}, 27^{\circ} 11^{\prime} 10^{\prime \prime} \mathrm{E}$, spruce forest with Vaccinium myrtillus and green mosses

04.06 .2015 IS

a51

NW part, SW from the lighthouse (Tytärsaaren majakka), 59 $51^{\prime} 15^{\prime \prime} \mathrm{N}, 27^{\circ} 11^{\prime} 08^{\prime \prime} \mathrm{E}$, old

02.06 .2015 IS spruce on the margin of a glade

a52 S shore, port area (Satama), $50 \mathrm{~m}$ of the seashore, $59^{\circ} 50^{\prime} 08^{\prime \prime} \mathrm{N}, 27^{\circ} 11^{\prime} 30^{\prime \prime} \mathrm{E}$, concrete constructions and oak trees

06.06.2015 IS

Cited specimens are deposited in the herbaria of the Botanical Museum of University of Helsinki (H), Komarov Botanical Institute (LE), Department of Botany, St. Petersburg State University (LECB), Museum of Evolution of Uppsala Univer- sity (UPS), Bergen University (BG) and Institute of Botany, Nature Research Centre in Vilnius (BILAS). Additionally we have investigated specimens of lichens and lichenicolous fungi collected earlier by Brenner (19th century) and other 


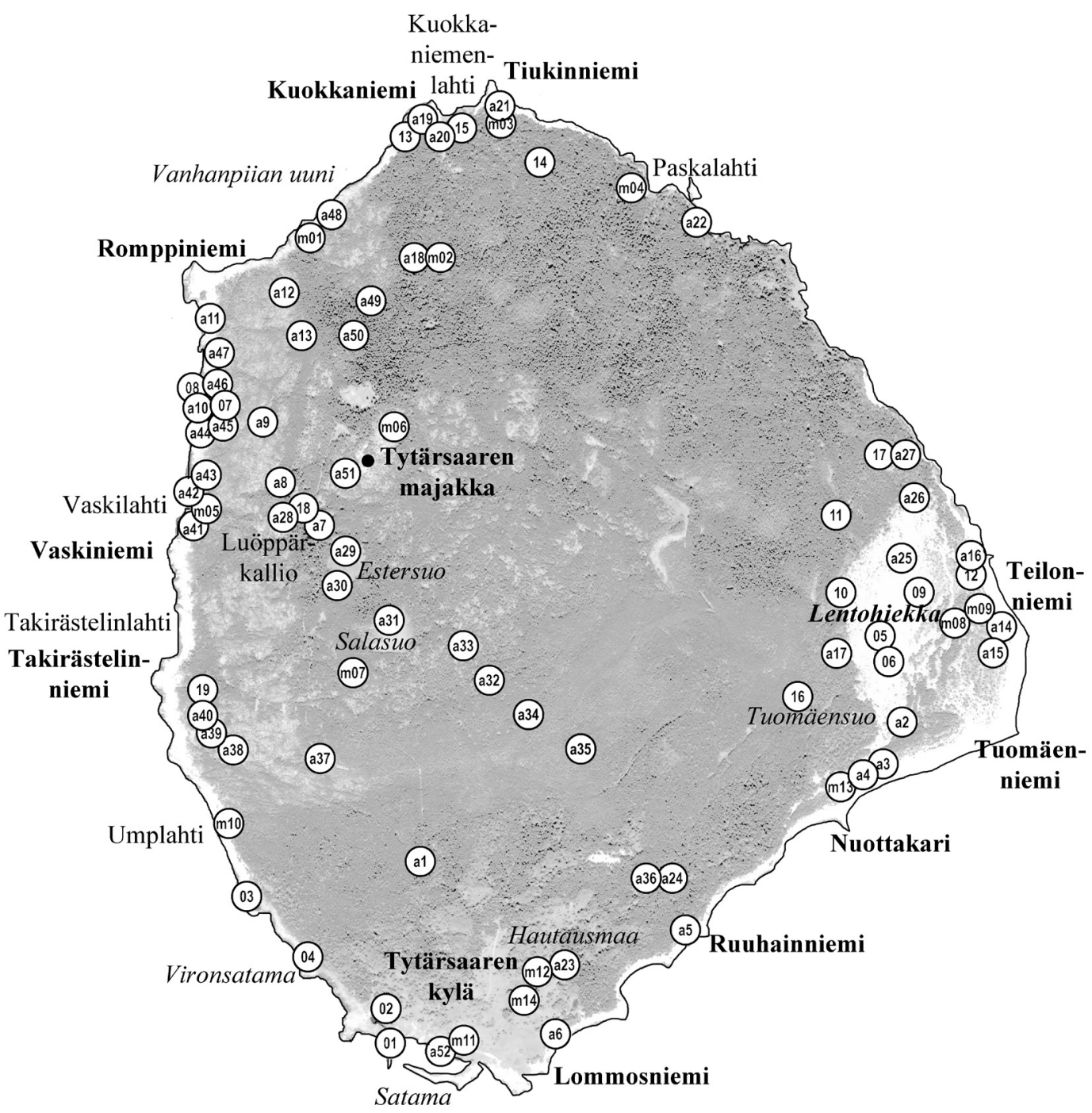

Fig. 1. The study area, Bolshoy Tuters Island (Tytärsaari), with location of collection sites.

researchers mentioned above (20th century). Lichen substances were analyzed by standard techniques of thin-layer chromatography with using solvent systems A, B, C and G (Orange et al., 2001) by the first and fifth authors. The nomenclature of taxa generally follows Nordin et al. (2011). For each species the substrate and locality numbers are presented; for selected taxa (either species new to Western Leningrad Region or species found in unusual habitats, or difficult for identification) diagnostic characters are added; for species new to Western Leningrad Region information about distribution in NW European Russia, Fennoscandia and Baltic countries is also given. Lichen substances are given for TLC-analyzed species. In the following list of species, lichenicolous fungi are marked with \# and non-lichenized fungus with + , and the subsequent abbreviations are used: LR Leningrad Region; SPb - St. Petersburg. 


\section{THE SPECIES}

\#Abrothallus caerulescens Kotte - on apothecia of Xanthoparmelia stenophylla on granite boulder; 12 (BILAS). The specimen contained only anamorphic Vouauxiomyces stage. Its conidia were longer than given by Ihlen \& Wedin (2008), 10.0-14.5 × 4.0-5.0 $\mu \mathrm{m}$ [5-7 $\times 4.0-6.0 \mu \mathrm{m}$ according to Ihlen $\&$ Wedin (2008)], but I+ blue reaction of vegetative hyphae and the host corresponded that of the characteristics of $A$. caerulescens.

ABsconditella lignicola Vězda \& Pišút - on lignum of Picea abies (L.) Karst.; 10, a23 (LE).

AcAROSPORA FUSCATA (Schrad.) Th. Fr. - on siliceous rocks; $\mathrm{m} 9, \mathrm{~m} 12,12,18$ (BG, LE, UPS L-116040; Andreev, 2002).

ACROCORDIA CAVATA (Ach.) R. C. Harris - on bark of Populus tremula L.; 2, 19 (H). Specialized species of biologically valuable forests in the Southern Taiga of North-Western European Russia (Andersson et al., 2009).

ALYXORIA VARIA (Pers.) Ertz \& Tehler - on bark of Populus tremula; 2, $19(\mathrm{H})$.

Amandinea Punctata (Hoffm.) Coppins \& Scheid. - on bark of Alnus glutinosa (L.) Gaertn., Pinus sylvestris L. and Quercus robur L.; m11, 1, 4, 15, a6 (BG, LE, UPS L-116089; Andreev, 2002).

ANAPTYCHIA CILIARIS (L.) Körb. - on seashore siliceous rocks; a11 (LE).

ANAPTYCHIA RUNCINATA (With.) J. R. Laundon - on seashore siliceous rock; a11 (LE). Known in LR from Hogland, where the species was collected in 1851-1939 (H; Hakulinen, 1962).

ANISOMERIDIUM POLYPORI (Ellis \& Everh.) M. E. Barr - on bark of Populus tremula and Sorbus aucuparia L.; 2, 11 (H, sub Pseudoschismatomma rufescens).

ARCTOPARMELIA CENTRIFUGA (L.) Hale - on siliceous rocks; a12, a37 (obs.). Red Data Book of LR (Tzvelev, 2000).

ARCTOPARMELIA INCURVA (Pers.) Hale - on siliceous rocks; a37 (obs.). Red Data Book of LR (Tzvelev, 2000).

ARTHONIA PUNCTIFORMIS Ach. - on bark of Alnus glutinosa and Betula sp.; 17, a22, a29, a33 (H, LECB).

ARTHONIA RAdiata (Pers.) Ach. - on bark of Alnus glutinosa; $15(\mathrm{H})$.

ARTHONIA RUANA A. Massal. - on bark of Alnus glutinosa; $15(\mathrm{H})$.

ARTHONIA SPADICEA Leight. - on bark of Alnus glutinosa and Picea abies; 11, 15, a21, a26 (H).
Indicator species of biologically valuable forests in the Southern Taiga of North-Western European Russia (Andersson et al., 2009). AsPicilia CINEREA (L.) Körb. - on siliceous rocks; 12, a6, a41, a48 (H).

AsPiCiLIA EPIGLYPTA (Norrl. ex Nyl.) Hue - on siliceous rocks; a48 (H). New to Russia. Distribution in Fennoscandia: Norway, Sweden, Finland (Nordin et al., 2011); not recorded in Baltic countries. Coastal crustose lichen with yellowish-grey cracked-areolate thallus and black prothallus. Aspicilia epiglypta contains norstictic acid as well as $A$. cinerea (L.) Körb. and A. intermutans (Nyl.) Arnold, but differs from both species in the size of the ascospores and conidia as well as in the number of apothecia (2-5) per areole (Fletcher et al., 2009).

ASPICILIA POLYCHROMA Anzi - on concrete; a6 (LE). New to the North-Western European Russia. In European Russia is known from Novaya Zemlya Island (Andreev et al., 1996). Distribution in Fennoscandia: Norway, Finland (LE; Nordin et al., 2011); not recorded in Baltic countries. Crustose lichen with grey or white-grey rather thin verruciform thallus with thin margin (R-). Apothecia 1-3 per areole, pruinose. Spores 13-18 × 8-10 $\mu \mathrm{m}$. (Wirth et al., 2013). Mainly arctic-alpine, perhaps circumpolar, chemically and morphologically variable species with optimum on calciferous siliceous rocks in sites with weak eutrophication.

ASPICILIA VERRUCIGERA Hue - on siliceous rocks; m9 (UPS L-116045). Collected from Tuters (no exact locality) by Brenner, 24.07.1868 (H 8004086: det. Adolf H. Magnusson, 1936).

Athallia Cerinella (Nyl.) Arup et al. - on bark of Acer platanoides L.; m11 (LE; Andreev, 2002).

ATHALLIA CERINELlOIDEs (Erichsen) Arup et al. - on iron; 3 (LE).

Athallia hOlOCARPa (Hoffm.) Arup et al. - siliceous rocks; 1, 13, a6 (LE; Andreev, 2002).

ATHALLIA PYRACEA (Ach.) Arup et al. - on bark of Populus tremula; 2 (LE).

ATHALLIA SCOPUlARIS (Nyl.) Arup et al. - on siliceous rocks; m5 (UPS L-116021).

\#ATHELIA ARACHNOIDEA (Berk.) Jülich - on algae on bark of Picea abies; a27 (LE).

\#BACHMANNIOMYCES UNCIALICOLA (Zopf) D. Hawksw. - on thallus of Cladonia uncialis subsp. biuncialis; 18 (BILAS). New to LR. Distribution in North-Western European Russia outside 
LR and SPb: Republic of Karelia (Fadeeva et al., 2007). Distribution in Fennoscandia and Baltic countries: Norway, Sweden, Finland (Nordin et al., 2011), Estonia (Randlane et al., 2016), Lithuania (Motiejūnaitè et al., 2011). Lichenicolous fungus, characterized by pycnidia immersed in convex gall-like swellings on podetia of Cladonia and abundant lens-shaped to pyriform simple conidia adhering in mucilage. Species of Epicladonia which may also form galls on Cladonia have subcylindrical to narrowly ellipsoid conidia which are not adhering in mucilage and may be simple or 1-septate (Hawksworth, 1981).

BACIDina INUNDATA (Fr.) Vězda s. 1. - on iron; a21 (LE).

Bacidina sulphuRella (Samp.) M. Hauck \& V. Wirth - on bark of Alnus glutinosa; 15 (H: det. Julia V. Gerasimova, 2016). New to LR. Recently published from St. Petersburg (Stepanchikova et al., 2015), but the specimens were re-identified (see Himelbrant et al., 2017). Distribution in North-Western European Russia outside LR and SPb: not recorded. Distribution in Baltic countries: Estonia (Randlane et al., 2016), Lithuania (Motiejūnaite et al., 2012); not recorded in Fennoscandia. The species is close to $B$. arnoldiana (Körb.) V. Wirth \& Vězda, from which differs by hook-shaped 0- to 5-septate conidia and inhabiting bark of trees (Brand et al., 2009). The specimen from Tuters is sterile, with abundant pycnidia.

BaEOMYCES RUfus (Huds.) Rebent. - on iron and soil; 10, a32 (H, sub Stereocaulon nanodes).

BiATORA EFFLORESCENS (Hedl.) Räsänen - on bark of Salix caprea L. and on mosses; 11, 19, a35 $(\mathrm{H})$.

BiATORA GLOBUlosa (Flörke) Fr. - on bark of Alnus glutinosa and lignum of Populus tremula; $2,15(\mathrm{H})$.

BiATORA HELVOLA Körb. ex Hellb. - on bark of Alnus glutinosa and Sorbus aucuparia; 14, 15, $19(\mathrm{H})$.

BiATORA OCELLIFORMIS (Nyl.) Arnold - on bark of Sorbus aucuparia; 14 (H, sub Pseudosagedia aenea).

Biatora sphaeroidiza (Vain.) Printzen \& Holien - on bark of Picea abies; a23 (H, sub Pseudosagedia aenea). Not recorded in NorthWestern European Russia outside LR and $\mathrm{SPb}$. The species is relatively rare also in Fennoscandia and Baltic countries, but it may be overlooked. Biatora sphaeroidiza differs from other Biatora species by having grey or greenish $(\mathrm{C}+\mathrm{red})$ apothecia (Printzen $\&$ Otte, 2005).

BRIANARIA SYLVICOLA (Flot. ex Körb.) S. Ekman \& M. Svensson - on iron and siliceous rocks; (18, a20, a32; H, LE).

BRODOA INTESTINIFORMIS (Vill.) Goward - on siliceous rocks; 7, a37 (LE, BILAS). Red Data Book of LR (Tzvelev, 2000).

BRYORIA CAPILLARIS (Ach.) Brodo \& D. Hawksw. on twigs of Picea abies and once on granite boulder; m2, 11, 12, 14 (LE; Andreev, 2002).

BRYORIA FUSCESCENS (Gyeln.) Brodo \& D. Hawksw. [incl. Bryoria subcana (Nyl. ex Stizenb.) Brodo \& D. Hawksw.] - on bark of Picea abies and lignum of Pinus sylvestris; $\mathrm{m} 7, \mathrm{~m} 14$, 6, a25 (BG, H 8004209, UPS L-116092; Andreev, 2002).

BRYORIA IMPLEXA (Hoffm.) Brodo \& D. Hawksw. on siliceous rocks; $12(\mathrm{H})$.

BRYORIA SIMPLICIOR (Vain.) Brodo \& D. Hawksw. on lignum of Pinus sylvestris; 6 (LE).

Buellia BADIA (Fr.) A. Massal. - on siliceous rocks; m9, 12 (H, UPS L-116054; Andreev, 2002).

BuElLIA DISCIFORMIS (Fr.) Mudd - on bark of Alnus glutinosa and Betula sp.; 17, a26 (H).

BuEllia GRISEOVIRENS (Turner \& Borrer ex Sm.) Almb. - on bark of Alnus glutinosa, Betula sp., Juniperus communis L., Picea abies, Pinus sylvestris and Sorbus aucuparia, on lignum; 2, 10, 11, 15-19, a10 (H, LE). Thalli contain atranorin, norstictic and connorstictic acids.

Calicium glaucellum Ach. - on snag of Pinus sylvestris; a34 (LE).

Calicium tigillare (Ach.) Pers. - on lignum of Pinus sylvestris; 6 (LE). Indicator species of biologically valuable forests in the Southern Taiga of North-Western European Russia (Andersson et al., 2009).

CAlicium VIRIDE Pers. - on bark of Picea abies; a46, a51.

CALOPLACA CHLORINA (Flot.) H. Olivier - on brick; a6 (LE).

CAloplaca Diphyodes (Nyl.) Jatta - on siliceous rocks; m5 (UPS L-116021, L-116029; Andreev, 2002).

Caloplaca saxicola (Hoffm.) Nordin - on limestone in former village; m12 (BG, LE, UPS L-116093; Andreev, 2002).

Candelariella aurella (Hoffm.) Zahlbr. - on bones, brick, concrete, iron; $\mathrm{m} 12$, 3, a6, a14 (H, LE; Andreev, 2002). 
Candelariella coralliza (Nyl.) H. Magn. - on siliceous rocks; 12 ( $\mathrm{H}$, sub Protoparmelia badia).

Candelariella efFlorescens R. C. Harris \& W. R. Buck - on bark of Populus tremula; $2(\mathrm{H})$.

CANDELARIELla lutella (Vain.) Räsänen - on bark of Populus tremula; $2(\mathrm{H})$.

CANDELARIELla REFLEXa (Nyl.) Lettau - on bark of Quercus robur; 1 (LE).

Candelariella vitellina (Hoffm.) Müll. Arg. - on iron and granite boulders; $\mathrm{m} 3, \mathrm{~m} 9, \mathrm{~m} 10,1$, 2, 4, a6 (H, UPS L-116046; Andreev, 2002).

\#CARBONEA SUPERSPARSA (Nyl.) Hertel - on thallus of Lecanora polytropa on siliceous stone; 12 ( $\mathrm{H}$, sub Protoparmelia badia).

CARBONEA VORTICOSA (Flörke) Hertel - on brick; a6 (LE). New to the North-Western European Russia. In European Russia is known from Murmansk Region (Urbanavichus et al., 2008). Distribution in Fennoscandia: Norway, Sweden, Finland (Nordin et al., 2011); not recorded in Baltic countries. Lichenized species of the genus Carbonea, characterized by thin olivaceous-brown thallus in irregular patches, numerous black apothecia with concave (crater-like) disc; asci 8-spored, Lecanora-type, spores simple, ellipsoid (Chambers et al., 2009).

Catillaria chalybeia (Borrer) A. Massal. - on siliceous rocks; 2, $13(\mathrm{H})$.

Catillaria nigroclavata (Nyl.) Schuler - on bark of Quercus robur; 1 (LE).

\#CERCIDOSPORA STEREOCAULORUM (Arnold) Hafellner - on thallus of Stereocaulon incrustatum on sandy soil; 9 (BILAS). New to the NorthWestern European Russia. In European Russia is known from Murmansk and Nenets regions (Zhurbenko, 2010). Distribution in Fennoscandia: Sweden, Norway (Nordin et al., 2011); not recorded in Baltic countries. The fungus differs from Cercidospora alpina Ihlen \& Wedin (also growing on Stereocaulon) by (2-)4(-8)-spored asci (4-spored in our specimen), (1-)3(-6)-septate spores (2-3-septate in our specimens) lacking perispore (Zhurbenko, 2010).

CetraRia ACUlEata (Schreb.) Fr. - on sandy soil; 5, 6, 9, 12, a5, a16 (H, LE).

CETRARIA ISLANDICA (L.) Ach. subsp. ISLANDICA - on soil; m8, m13, 12, a3, a4, a16, a25, a37 (Andreev, 2002).

CETRARIA MURICATA (Ach.) Eckfeldt - on soil; a40 (H). Collected from Tuters (no exact locality) by Brenner, 24.07.1868 (H 8004371: det. I. Kärnefelt, 1982).

Cetraria SEPIncola (Ehrh.) Ach. - on bark of Betula sp. and Pinus sylvestris; 6, a29.

Cetrariella commixta (Nyl.) A. Thell \& Kärnefelt - on siliceous rocks; 7 (LE). Red Data Book of LR (Tzvelev, 2000).

Chaenotheca chrysocephala (Turner ex Ach.) Th. Fr. - on bark of Picea abies and Pinus sylvestris, on lignum of Pinus sylvestris; 10, 14, a27, a31, a35, a46, a50.

Chaenotheca ferruginea (Turner ex Sm.) Mig. on bark of Picea abies and Pinus sylvestris, on lignum; m6, 11, 14, 16, 17, a31, a35, a50 (Andreev, 2002).

CHAENOTHECA FURFURACEA (L.) Tibell - on siliceous rocks and upturned roots; a1, a28 (LE).

Chaenotheca stemonea (Ach.) Müll. Arg. - on bark of Picea abies; 11, a50 (LE). Indicator species of biologically valuable forests in the Southern Taiga of North-Western European Russia (Andersson et al., 2009).

Chaenotheca trichialis (Ach.) Th. Fr. - on bark of Picea abies and snag of Pinus sylvestris; 11 , a34 (LE).

ChAENOTHECOPSIS SUBPAROICA (Nyl.) Tibell - on thallus of Haematomma ochroleucum on siliceous rock; a28 (LE).

Circinaria CAEsiocinerea (Nyl. ex Malbr.) A. Nordin, S. Savić \& Tibell - on siliceous rocks; m1 (UPS L-116080; Andreev, 2002).

Circinaria contorta (Hoffm.) A. Nordin, S. Savić \& Tibell - on soil; a6 (LE).

Circinaria Gibbosa (Ach.) A. Nordin, S. Savić \& Tibell - on siliceous rocks; $12(\mathrm{H}$, sub Acarospora fuscata).

Cladonia AmaURocraea (Flörke) Schaer. - on soil and lignum; m6, 7, 18, a2 (UPS L-116066; Andreev, 2002).

Cladonia ARbuscula (Wallr.) Flot. subsp. arbusCULA - on soil; m6, m13, m14, 7, 9, 18, a2, a6 (H 8004420; Andreev, 2002); subsp. MITIS (Sandst.) Ruoss- on soil; m8, 5, 10, 12, 18 (H; Andreev, 2002).

Cladonia Bellidiflora (Ach.) Schaer. - on soil and lignum; m8, 7, 18 (BG, H, LE; Andreev, 2002).

Cladonia borealis S. Stenroos - on soil; 7,10 , 18 , a38 $(\mathrm{H})$.

Cladonia botrytes (K. G. Hagen) Willd. - on soil; m8, 9 (LE; Andreev, 2002).

Cladonia carneola (Fr.) Fr. - on sand; 5 (LE). 
Cladonia cenotea (Ach.) Schaer. - on bark and lignum of Pinus sylvestris, on sandy soil; m6, 16, a15, a31 (H; Andreev, 2002).

Cladonia chlorophaea (Flörke ex Sommerf.) Spreng. - on soil; 4, 6, a6 (LE; Andreev, 2002). Thalli contain fumarprotocetraric acid.

Cladonia Ciliata Stirt. f. Flavicans (Flörke) Ahti \& DePriest - on soil; 10 (H). New to North-Western European Russia. In European Russia is known from Kaliningrad Region (Dedkov et al., 2007). Distribution in Fennoscandia and Baltic countries: Norway, Sweden, Finland (Nordin et al., 2011), Estonia (Randlane et al., 2016), Latvia (Motiejūnaitè \& Piterāns, 1998), Lithuania (Motiejūnaite, 1999). The species of Cladina section with slender regularly branched yellowish podetia, brown towards the apices, $\mathrm{P}+$ red; pycnidia contain red slime (Ahti \& Stenroos, 2013). It is an oceanic species widespread on coasts of Poland, Lithuania, Latvia, Estonia and SW Finland (and westwards); Tuters Island is the easternmost locality of this species in Europe.

Cladonia COCCIFERA (L.) Willd. - on primary soil on rocks; m6, a40 (LE; Andreev, 2002).

Cladonia Coniocraea (Flörke) Spreng. - on bark of Picea abies and Pinus sylvestris, on lignum; m8, 11, 14, 17-19 (Andreev, 2002).

Cladonia CORNUTA (L.) Hoffm. subsp. CORNUTA - on bark of Pinus sylvestris, on lignum, soil and sand; $\mathrm{m} 6, \mathrm{~m} 8, \mathrm{~m} 9,5,9,10,17, \mathrm{a} 2, \mathrm{a} 3, \mathrm{a} 6$ (UPS L-116058; Andreev, 2002).

Cladonia CRISPATA (Ach.) Flot. var. CRISPATA - on lignum and soil; m8, 9, 10, 18, a2 (H, BG, H, UPS L-116033; Andreev, 2002); var. CETRARIIFORMIS (Delise) Vain. - on sandy soil; m6 (UPS L-116057).

Cladonia Cyanipes (Sommerf.) Nyl. - on soil; 9 (LE).

Cladonia deformis (L.) Hoffm. - on bark of Pinus sylvestris, on lignum and soil; $\mathrm{m} 8, \mathrm{~m} 15,9$, 10, 17 (H, UPS L-116031; Andreev, 2002).

Cladonia digitata (L.) Hoffm. - on bark of Pinus sylvestris and on lignum; 11, 16, 17, 19.

Cladonia Fimbriata (L.) Fr. - on bark of Picea abies and Pinus sylvestris, on lignum and soil; $\mathrm{m} 8$, 9, 11, 12, 14, 16, 17, a6 (Andreev, 2002).

Cladonia Floerkeana (Fr.) Flörke - on lignum and soil; m8, 7 (H; Andreev, 2002).

Cladonia furcata (Huds.) Schrad. - on soil; m6, m8, 10, 12, 18, a3, a6 (BG, H, LE, UPS L-116057; Andreev, 2002).
Cladonia Gracilis (L.) Willd. subsp. Gracilis - on soil; m6, 7, 10, 18, a18 (H, UPS L-116055; Andreev, 2002); subsp. TURBINATA (Ach.) Ahti - on soil and lignum; m6, m8, m15, 9, 10, 18, a2 (H, BG, LE UPS L-116032; Andreev, 2002).

Cladonia grayi G. Merr. ex Sandst. - on soil; m15 (H). Thallus UV+ blue.

Cladonia MaCilenta Hoffm. - on lignum and soil; m6, 7, 9, 10, 12 (UPS L-116034, L-116072; Andreev, 2002).

Cladonia Macrophylla (Schaer.) Stenh. - on soil; 7 (H). Red Data Book of LR (Tzvelev, 2000).

Cladonia MERochlorophaEa Asahina - on soil; 9, 12 (LE). Thalli contain merochlorophaeic and 4'-O-methylchlorophaeic acids.

CLADONIA OCHROCHLORA Flörke - on lignum; 11 $(\mathrm{H})$.

Cladonia PHyllophora Hoffm. - on soil; m6, m8, 5, 7, 10, 12, a5 (BG, H, LE, UPS L-116059; Andreev, 2002).

Cladonia Pleurota (Flörke) Schaer. - on soil and lignum; m6, m15, 9, 10, 18, a2 (H; Andreev, 2002).

Cladonia PyXidata (L.) Hoffm. - on soil; 7, 10, 12, 18, a6, a8, a37. Collected from Tuters (no exact locality) by Balashova, 1993 (LECB; Alexeeva, 2005).

Cladonia Rangiferina (L.) F. H. Wigg. - on soil; m6, m13, 7, 9, 10, 18, a2, a6 (H; Andreev, 2002).

Cladonia Rangiformis Hoffm. - on soil; a5, a6 $(\mathrm{H}, \mathrm{LE})$. New to North-Western European Russia. The nearest locality in European Russia is in Kaliningrad Region (Dedkov et al., 2007). Distribution in Fennoscandia and Baltic countries: Norway, Sweden, Finland (Nordin et al., 2011), Estonia (Randlane et al., 2016), Latvia (Piterāns, 2001), Lithuania (Motiejūnaitè, 1999). Podetia are irregularly dichotomously branched, form dense cushions, brownish toward the tops. Close to $C$. furcata, but distinguished by pale greyish colour and usually by the P- reaction (Ahti \& Stenroos, 2013). Distributed mostly along the coasts of the Atlantic.

Cladonia ReI Schaer. - on soil, on bark and lignum of Pinus sylvestris; 5-7, 9, 12, 17, a2 (LECB).

Cladonia scabriuscula (Delise) Nyl. - on soil; $\mathrm{m} 14,12, \mathrm{a} 4, \mathrm{a} 6, \mathrm{a} 16(\mathrm{H})$. Collected from Tuters (no exact locality) by Balashova, 1993 (Alexeeva, 2005). 
Cladonia squamosa Hoffm. - on lignum and soil; m6, 7, 10, 18, 19 (H; Andreev, 2002).

Cladonia stellaris (Opiz) Pouzar \& Vězda - on soil; m6, m13, 18, a3, a37 (Andreev, 2002).

Cladonia STYGia (Fr.) Ruoss - on soil; 18, a2 (LE).

Cladonia subulata (L.) F. H. Wigg. - on sandy soil; $\mathrm{m} 8, \mathrm{~m} 9, \mathrm{~m} 15,5,7,10,12$ (BG, H, LE, UPS L-116056; Andreev, 2002).

Cladonia sulphurina (Michx.) Fr. - on lignum; 18.

Cladonia tURgida Hoffm. - on soil; m2, m6, 18, a2, a8, a17, a37 (BG, LE, UPS L-116067, L-116076; Andreev, 2002).

Cladonia uncialis (L.) F. H. Wigg. subsp. BiUnciaLIS (Hoffm.) M. Choisy - on soil; 7, 18, a2, a13, a37; subsp. UNCIALIS - on soil; m6, a3 (Andreev, 2002).

Cladonia verticillata (Hoffm.) Schaer. - on soil; $\mathrm{m} 8,12,18$, a2 (H; Andreev, 2002).

Cliostomum GRIfFithil (Sm.) Coppins - on bark of Alnus glutinosa and Picea abies; 15, a21, a46 $(\mathrm{H})$.

\#Clypeococcum hypocenomycis D. Hawksw. - on thallus of Hypocenomyce scalaris on lignum of Pinus sylvestris; $6(\mathrm{H})$.

Coenogonium PINETI (Ach.) Lücking \& Lumbsch - on bark of Alnus glutinosa, Picea abies, Pinus sylvestris and Salix caprea; 11, 14-16, 18, a21, a26, a27 (H).

ENTEROGRAPHA ZONATA (Körb.) Källsten ex Torrente \& Egea-on siliceous rock; a28 (LE). Thallus contains confluentic, 2'-0-methylmicrophyllinic and 2'-0-methylperlatolic acids.

Evernia MESOMORPHA Nyl. - on bark of Picea abies; a16.

Evernia PRUNASTRI (L.) Ach. - on bark of Picea abies and Pinus sylvestris; 4, 11.

Felipes leucopellaeus (Ach.) Frisch \& G. Thor - on bark of Picea abies; 14, a35, a49 (LE). Specialized species of biologically valuable forests in the Southern Taiga of NorthWestern European Russia (Andersson et al., 2009).

Fellhanera subTilis (Vězda) Diederich $\&$ Sérus. on bark of Vaccinium myrtillus; 18, a18 (H).

FlaVoPlaca MARINA (Wedd.) Arup et al. - on siliceous rocks; m3, 1, 8, 13 (H, LE; Andreev, 2002).

FlaVoPlaCA MiCROTHALlina (Wedd.) Arup et al. - on siliceous rocks; $\mathrm{m} 1$ (LE; Andreev, 2002).

Fuscidea ARBoricola Coppins \& Tønsberg - on bark of Alnus glutinosa; 15 (fertile), 19 (H; LE). Thalli contain fumarprotocetraric acid.

FuscidEA CYATHOIDES (Ach.) V. Wirth \& Vězda - on siliceous rocks; a43, a48 $(\mathrm{H})$.
Fuscidea PRAERUPTORUM (Du Rietz \& H. Magn.) V. Wirth \& Vězda - on siliceous rocks; 13, a28 (H, LE). New to Russia. Distribution in Fennoscandia and Baltic countries: Norway, Sweden, Finland (Nordin et al., 2011), Estonia (Randlane et al., 2016), Lithuania (Motiejūnaite et al., 2015). The species has pale to brown areolate thallus with black prothallus and ochre- to cream-coloured punctiform soralia which react $\mathrm{Pd}+$ yellow, $\mathrm{KC}+$ red, UV+ faintly yellowish; apothecia are very rare (Gilbert et al., 2009). Thalli contain alectorialic acid.

Fuscidea PUSILla Tønsberg - on bark of Betula sp., Juniperus communis, Picea abies, Pinus sylvestris and Salix sp., on lignum of Picea abies; 10, 11, 14, 16-19, a23, a27, a29 (H, LE). Thalli contain divaricatic acid.

GRAPHIS SCRIPTA (L.) Ach. s. 1. - on bark of Alnus glutinosa; 15, a21 $(\mathrm{H})$.

Gyalolechia flavorubescens (Huds.) Søchting et al. - on bark of Populus tremula; 2, a36 (H).

HAEMATOMMA OCHROLEUCUM (Neck.) J. R. Laundon var. OCHROLEUCUM - on siliceous rocks; a 44, a48 (LE). Thalli contain usnic acid, zeorin, atranorin and porphyrilic acid; var. PORPHYRIUM (Pers.) J. R. Laundon - on siliceous rocks; a28 (LE). Thallus contains zeorin, atranorin, porphyrilic acid and unidentified fatty acid.

\#Homostegia Piggotil (Berk. \& Broome) P. Karst. - on thallus of Parmelia omphalodes on siliceous rock; a45 $(\mathrm{H})$.

HydROPUnCTARIA MAURA (Wahlenb.) Keller, Gueidan $\&$ Thüs - on siliceous rocks $(\mathrm{m} 1, \mathrm{~m} 5,1$, 3, 8, 13 (BG, LE, UPS L-116078, L-116023, L-116071; Andreev, 2002). The thalli of the investigated specimens are rather thick and contain brown pigment in the pseudocortex. In contrast, the similar species $H$. aractina (Wahlenb.) Orange has thinner thallus and a green to green-brown pigment (Orange 2012).

HyPOCENOMYCE SCALARIS (Ach.) M. Choisy - on bark and lignum of Pinus sylvestris (m6, 6, 16, 17, a10, a31 (BG, H, LE, UPS L-116071; Andreev, 2002).

Hypogymnia physodes (L.) Nyl. - on bark of Alnus glutinosa, Betula sp., Picea abies, Pinus sylvestris, Populus tremula, Salix sp. and Vaccinium uliginosum L., on lignum, siliceous rocks, sandy soil; $\mathrm{m} 2, \mathrm{~m} 4, \mathrm{~m} 6-9$, 5-7, 10-12, 14-19, a29, a31 (BG, H, LE, 
UPS L-116061; Andreev, 2002). Collected from Tuters (no exact locality) by Brenner, 25.07.1868 (H 8005048).

Hypogymnia Tubulosa (Schaer.) Hav. - on bark of Picea abies, Pinus sylvestris and Salix sp., on siliceous rocks; 5-7, 10-12, 14, 18, a29 (H). Collected from Tuters (no exact locality) by Brenner, 1868 (H 8005081, 8000440).

IMSHAUGia ALEURITES (Ach.) S. L. F. Meyer - on bark of Picea abies and Pinus sylvestris; 10, a46 (LE).

IONASPIS LACUSTRIS (With.) Lutzoni - on siliceous rocks; a30, a48 $(\mathrm{H})$.

LASALLIA PUSTULATA (L.) Mérat - on siliceous rock; a40 (not collected).

LeCANACTIS ABIETINA (Ach.) Körb. - on bark of Picea abies; 11, 14, a27, a35, a49, a50 (H). Specialized species of biologically valuable forests in the Southern Taiga of North-Western European Russia (Andersson et al., 2009).

LECANiA CYRTELla (Ach.) Th. Fr. - on bark of Populus tremula; 2, a36 $(\mathrm{H})$.

LECANIA ERYSIBE (Ach.) Mudd - on iron; 3 (LE).

LeCANia NAEGELII (Hepp) Diederich \& van den Boom - on bark of Populus tremula; $2(\mathrm{H})$.

LECANORA AITEMA (Ach.) Hepp - on bark of Alnus glutinosa and on lignum; 15, a10 $(\mathrm{H})$.

LeCANORA Albellula (Nyl.) Th. Fr. - on bark of Pinus sylvestris; a29 (LE).

LeCANORA Allophana Nyl. - on bark of Populus tremula; 2, 19 (LE).

LECANORA ARGENTATA (Ach.) Malme - on bark of Alnus glutinosa; m4, a2 1 (H; (Andreev, 2002).

LeCANora CAdubriae (A. Massal.) Hedl. - on lignum of Pinus sylvestris; $6(\mathrm{H})$.

LECANORA CAESIOSORA Poelt - on siliceous rocks; 7 , a40 (LE). Thalli contain atranorin, chloratranorin, fatty acids and unknown substance.

LECANORA CAMPESTRIS (Schaer.) Hue - on siliceous rocks; m6 (UPS L-116099; Andreev, 2002).

LECANORA CARPINEA (L.) Vain. - on bark of Acer platanoides, Alnus glutinosa, Fraxinus excelsior L., Padus avium Mill., Pinus sylvestris, Populus tremula, Quercus robur and Sorbus aucuparia; m4, m11, 1, 2, 12, 15, 19 (BG, H, LE, UPS L-116082, L-116082; Andreev, 2002). Collected from Tuters (no exact locality) by Brenner, 25.07.1868 (H 8005168).

LECANORA CENISIA Ach. - on siliceous rocks; 8, $13(\mathrm{H})$.

LECANORA CHLAROTERA Nyl. - on bark of Alnus glutinosa, Betula sp., Pinus sylvestris, Populus tremula and Quercus robur, $\mathrm{m} 11,1,2$,
5, 6, 12, 15, a21, a29 (H, UPS L-116087; Andreev, 2002).

LECANORA CIRCUMBOREALIS Brodo \& Vitik. - on bark of Salix sp. and lignum of Pinus sylvestris; 6, a29 (LE).

LECANORA COMPALLENS van Herk et Aptroot - on bark of Alnus glutinosa and Pinus sylvestris; 4, 15 (LE). Thalli contain usnic acid and zeorin.

LECANORA HELICOPIS (Wahlenb.) Ach. - on seashore granite boulders; m1, 1, 3, $13(\mathrm{H}$; Andreev, 2002).

LECANORA HYPOPTELLA (Nyl.) Grummann - on bark of Pinus sylvestris; 16, 17 (LE).

LECANORA INTRICATA (Ach.) Ach. - on siliceous rocks and on lignum; $\mathrm{m} 9$, a10, a41 (H, UPS L-116040, sub Acarospora fuscata).

LECANORA MARGINATA (Schaer.) Hertel \& Rambold - on siliceous rocks; m9 (LE, UPS L-116053; Andreev, 2002).

LECANORA POLYTROPA (Ehrh. ex Hoffm.) Rabenh. - on siliceous rocks, iron and rubber; $\mathrm{m} 9$, $\mathrm{m} 12,8,12,18, \mathrm{a} 6, \mathrm{a} 21, \mathrm{a} 39, \mathrm{a} 41$ (BG, H, LE, UPS L-116039; Andreev, 2002).

LECANORA PULICARIS (Pers.) Ach. - on bark of Alnus glutinosa, Betula sp., Picea abies, Pinus sylvestris, Salix sp. and Sorbus aucuparia, on lignum; $\mathrm{m} 4,6,10,11,14,16-19$, a10, a26, a29 (H; Andreev, 2002).

LECANORA RIMICOLA H. Magn. - on siliceous rocks; m10, 3, 13 (H; Andreev, 2002).

LECANORA RUPICOLA (L.) Zahlbr. - on siliceous rocks; m9, 12 (BG, H, LE, UPS L-116038; Andreev, 2002).

LECANORA SUBINTRICATA (Nyl.) Th. Fr. - on bark and lignum of Pinus sylvestris; 6, $18(\mathrm{H})$.

LECANORA SYMmicta (Ach.) Ach. - on bark of Alnus glutinosa, Betula sp., Picea abies, Pinus sylvestris, Salix sp., lignum of Pinus sylvestris and Populus tremula; m4, m11, 2, 6, 12, 15, 17, a29, a46 (Andreev, 2002).

LECANORA UMBrina (Ach.) A. Massal. - on bark of Quercus robur, m11 (UPS L-116089, sub Amandinea punctata).

LECANORA VARIA (Hoffm.) Ach. - on bark of Betula sp. and lignum; m8, 6, a29 (H; Andreev, 2002).

LECIDEA FUSCOATRA (L.) Ach. - on siliceous rocks; m9 (BG, LE, UPS L-116041; Andreev, 2002).

LECIDEA LAPICIDA (Ach.) Ach. var. LAPICIDA - on siliceous rock; a41 (LE); var. PANTHERINA Ach. - on siliceous rocks; $\mathrm{m} 3, \mathrm{~m} 9, \mathrm{~m} 10, \mathrm{~m} 12$, 12 (BG, H, LE, UPS L-116043, L-116044; Andreev, 2002). 
Lecidea lithophila (Ach.) Ach. - on siliceous rocks; 7, a41 (LE).

Lecidea nYlanderi (Anzi) Th. Fr. - on bark of Betula sp., Juniperus communis, Picea abies and Pinus sylvestris, on lignum of $P$. sylvestris; 7, 11, 16-18, a31, a46 (H).

LECIDEA TURGIDULA Fr. - on bark and lignum of Pinus sylvestris; 16, 18, a31 (H).

LECIDELLA CARPATHICA Körb. - on siliceous rocks; m6 (LE; Andreev, 2002).

Lecidella elaeochroma (Ach.) M. Choisy [incl. $L$. achristotera (Nyl.) Hertel \& Leuckert] - on bark of Acer platanoides, Alnus glutinosa, Betula sp., Fraxinus excelsior, Padus avium, Populus tremula, Quercus robur and Sorbus aucuparia; $\mathrm{m} 11,1,2,15,19$, a36 (H, LE, UPS L-116083, L-116086; Andreev, 2002).

LECIDELLA FLAVOSOREDIATA (Vězda) Hertel et Leuckert - on bark of Alnus glutinosa; 15, a21 (LE). Thalli contain arthothelin.

LECIDELla STIGMATEA (Ach.) Hertel \& Leuckert - on concrete and siliceous rock; a6, a41 (LE).

LEPRARIA BOREALIS Loht. et Tønsberg - on siliceous rocks; 7, a39 (LE). Thalli contain atranorin and roccellic/angardhianic acid.

LEPRARIA ELOBATA Tønsberg - on bark of Alnus glutinosa, Picea abies, Pinus sylvestris and Sorbus aucuparia, on lignum of Salix caprea; 11, 14, 15, 17-19, a26, a49 (H, LE). Thalli contain atranorin, zeorin and stictic acid complex.

LEPRARIA INCANA (L.) Ach. - on bark of Picea abies and Pinus sylvestris, on lignum of Salix caprea and on upturned roots; 11, 14, a27, a48 $(\mathrm{H}, \mathrm{LE})$. Thalli contain atranorin, zeorin and divaricatic acid.

LEPRARIA JACKII Tønsberg - on bark of Picea abies, Pinus sylvestris and Juniperus communis, on upturned roots; $\mathrm{m} 2,11,16,17,19$, a34, a49 (LE). Thalli contain atranorin, roccellic/angardhianic, jackinic/rangiformic and norjackinic/norrangiformic acids.

LEPRARIA LOBIFICANS Nyl. - on bark of Picea abies; 11,14 , a50 (LE).

LEPRARIA MEMBRANACEA (Dicks.) Vain. - on siliceous rocks; 7 , a28, a37 (LE). Thalli contain pannaric acid and fatty acids.

LEPRARIA NEGLECTA (Nyl.) Lettau - on siliceous rocks and saxicolous mosses; $7,18(\mathrm{H}, \mathrm{LE})$. Thalli contain alectorialic and roccellic/ angardhianic acids.

LEPTORHAPHIS ATOMARIA (Ach.) Szatala - on bark of Populus tremula; a36 (LE).
LEPTORHAPHIS EPIDERMIDIS (Ach.) Th. Fr. - on bark of Betula sp.; a29, a33 (LE).

\#Lichenoconium ERodens M. S. Christ. \& D. Hawksw. - on thalli of Parmelia omphalodes subsp. discordans, Hypogymnia physodes and Imshaugia aleurites; 5, a37, a46 (BILAS).

\#Lichenodiplis lecanorae (Vouaux) Dyko \& D. Hawksw. - on apothecia and thallus of Athallia holocarpa; $1,13(\mathrm{H})$.

LicheNOMPHALIA UMBELLIFERA (L.: Fr.) Redhead et al. - on lignum, soil; 18, a44 (H).

Melanelia hepatizon (Ach.) A. Thell - on siliceous rocks; m9, 12 (LE; Andreev, 2002). Red Data Book of LR (Tzvelev, 2000).

Melanelia stygia (L.) Essl. - on siliceous rocks; m9, 7, 12, a9 (LE; Andreev, 2002). Red Data Book of LR (Tzvelev, 2000).

Melanelixia fuliginosa (Fr. ex Duby) O. Blanco et al. - on siliceous rocks; $3,7,8,15$, a43, a47 (H).

MelaneliXia glabratula (Lamy) Sandler \& Arup on bark of Alnus glutinosa and Picea abies; 15 , a $46(\mathrm{H})$.

MELANELiXIA SubAURifera (Nyl.) O. Blanco et al. on bark of Quercus robur, 1 (LE).

Melanohalea eXasperatula (Nyl.) O. Blanco et al. - on bark of Alnus sp., Salix sp. and Pinus sylvestris; m4, 5, 6, 10, 12, a29 (UPS L-116075; Andreev, 2002).

Melanohalea olivacea (L.) O. Blanco et al. - on bark of Pinus sylvestris and Sorbus aucuparia; m4, 12 (BG, LE; Andreev, 2002).

MicAREA Botryoides (Nyl.) Coppins - on bark of Pinus sylvestris; 11 (LE). New to LR. Distribution in North-Western European Russia outside LR and SPb: Republic of Karelia (Fadeeva et al., 2007). In Russia also known from Kaliningrad region (Czarnota, 2007). Distribution in Fennoscandia and Baltic countries: Norway, Sweden, Finland (Nordin et al., 2011), Lithuania (Motiejūnaite, 1999). Differs from other species by black stalked pycnidia with walls dull greenish to olive-brown in squash preparation, $\mathrm{K}$ - or $\mathrm{K}^{+}$ green intensifying (Coppins, 1983; Czarnota, 2007).

Micarea byssacea (Th. Fr.) Czarnota et al. - on bark of Picea abies and Pinus sylvestris, on lignum of Picea abies; 11, 16, a23 (LE). New to Russia. Distribution in Fennoscandia and Baltic countries: Sweden, Finland (Nordin et al., 2011), Estonia, Lithuania (Czarnota, 
Guzow-Krzemińska, 2010). Thalli contain methoxymicareic acid. Differs from Micarea micrococca by darker apothecia containing "sedifolia grey" pigment $(\mathrm{K}+$ violet) in epihymenium and thallus formed by goniocysts. Sometimes $M$. byssacea develops pale apothecia, but unlike $M$. micrococca they are usually adnate (Czarnota, GuzowKrzemińska, 2010).

Micarea denigrata (Fr.) Hedl. - on lignum; a10 (H).

Micarea melaena (Nyl.) Hedl. - on bark of Pinus sylvestris; 11.

MicAREA MicRococca (Körb.) Gams ex Coppins on bark of Picea abies and Pinus sylvestris, on lignum; 11, 14, 16, 18, 19, a18 (H, LE).

Micarea NitschKeANA (J. Lahm ex Rabenh.) Harm. - on bark of Betula sp.; a29 (H).

Micarea PEliocarpa (Anzi) Coppins \& R. Sant. on soil; a44 $(\mathrm{H})$.

MiRiquidica DEUsta (Stenh.) Hertel \& Rambold on siliceous rocks; 7 (LE).

MiRIQUidiCA GRISEOATRA (Flot.) Hertel \& Rambold - on siliceous rocks; a41 (LE). New to LR. Distribution in North-Western European Russia outside LR and $\mathrm{SPb}$ : Republic of Karelia (Fadeeva et al., 2007). Distribution in Fennoscandia: Norway, Sweden, Finland (Nordin et al., 2011); not recorded in Baltic countries. Thallus consists of grey-brown to dark bluish grey, rounded convex areoles; apothecia black, sessile, with constricted base; ascospores simple, 9-13(-14) × (4-)5-7 $\mu \mathrm{m}$. Similar to Miriquidica leucophaea (Flörke ex Rabenh.) Hertel \& Rambold, from which differs in the darker coloured matt and more frequently lobate areoles (Giavarini et al., 2009).

MonTANELIA DisJuncta (Erichsen) Divakar et al. on siliceous rocks; $\mathrm{m} 5, \mathrm{~m} 10,8,12$, a $41(\mathrm{H}$, LE; Andreev, 2002).

MYRIOLECIS DISPERSA (Pers.) Śliwa et al. - on brick, calcareous stone and concrete; $\mathrm{m} 12$, a6 (LE; Andreev, 2002).

Myriolecis HAgeniI (Ach.) Śliwa et al. - on bark of on bark of Alnus sp., Populus tremula, Quercus robur and Sorbus aucuparia, on bones; m4, 1, 2, 19, a14 (H, LE).

Myriolecis SAlina (H. Magn.) Śliwa et al. - on siliceous rocks; m3, m5, m10 (UPS L-116028; Andreev, 2002).

MyRiolecis SEMIPALlida (H. Magn.) Śliwa et al. - on bones and concrete; a6, a14 (H).
Myriospora SMARAgdula (Wahlenb. ex Ach.) Nägeli ex Uloth - on siliceous rocks; $4(\mathrm{H})$.

NAETROCymbe PUnCTIFormis (Pers.) R. C. Harris on bark of Alnus glutinosa, Betula sp., Populus tremula and Sorbus aucuparia; m4, m11, 2, 15, 19, a22 (H; Andreev, 2002). Collected from Tuters (no exact locality) by Brenner, 25.07.1868 (H 8005168).

Ochrolechia ANDROGYNa (Hoffm.) Arnold - on bark of Picea abies and on dead mosses over rock; 14, a45 (LE). Thalli contain lecanoric acid, gyrophoric acid and "androgyna Bunknowns” 1, 2, 3 (see Kukwa, 2011).

OCHROLECHIA ARBOREA (Kreyer) Almb. - on bark of Pinus sylvestris; 17 (LE). Thallus contains lecanoric, gyrophoric acids and lichexanthone.

OCHROLECHIA MiCROSTICTOIDES Räsänen - on bark of Betula sp., Picea abies and Pinus sylvestris, on lignum of Pinus sylvestris; 6, $11,17,18(\mathrm{H}, \mathrm{LE})$. Thalli contain variolaric acid, lichesterinic acid and "microstictoidesunknowns" (see Kukwa, 2011).

OPEgRAPHA VUlgata (Ach.) Ach. - on bark of Picea abies; 11, $14(\mathrm{H})$.

PachyPhiale Fagicola (Hepp) Zwackh - on bark of Acer platanoides, Populus tremula, Quercus robur and Sorbus aucuparia; m11, 1, 19, a36 (H; Andreev, 2002).

Palicella filamentosa (Stirt.) Rodr. Flakus \& Printzen - on lignum; 6, a10 (H).

PARMElia ERnStiae Feuerer \& A. Thell - on bark of Alnus glutinosa and Quercus robur, 1, 15 (H, LE). New to the North-Western European Russia. In European Russia is known from Caucasus (Urbanavichus \& Urbanavichene, 2008). Distribution in Fennoscandia and Baltic countries: Sweden, Finland (Nordin et al., 2011), Estonia (Randlane et al., 2016), Lithuania (Motiejūnaitè et al., 2008). Corticolous species close to $P$. saxatilis and $P$. serrana, from which differs by partly pruinose lobes and pruinose isidia typically spread over the surface in the central parts of a thallus (Thell et al., 2011).

Parmelia omphalodes (L.) Ach. subsp. DiscordANS (Nyl.) Skult - on siliceous rocks; $\mathrm{m} 12$, 7, a37, a41, a43, a45 (H; Andreev, 2002). Collected from Tuters (no exact locality) by Brenner, 28.07.1868, det. H. Skult, 1983 (H 8000439, 8000440).

Parmelia saXatilis (L.) Ach. - siliceous rocks, also on bark and lignum of Picea abies and 
Pinus sylvestris along the seashore; $\mathrm{m} 4-6$, $\mathrm{m} 9, \mathrm{~m} 12,2,4,7,8,11,12,15,18, \mathrm{a} 10$, a11, a41, a45 (BG, H, LE, UPS L-116049, L-116074; Andreev, 2002).

PARMELIA SUlCATA Taylor - on bark of Alnus glutinosa, Picea abies, Pinus sylvestris, Quercus robur, Salix sp. and Sorbus aucuparia, on lignum of Populus tremula and on siliceous rocks; $\mathrm{m} 4, \mathrm{~m} 11,1,2,10-12,14,15,17$, a29, a46 (H; Andreev, 2002).

PARMELIOPSIS AMBIGUA (Wulfen) Nyl. - on bark of Alnus glutinosa, Betula sp., Picea abies and Pinus sylvestris, on lignum; m6, 6, 7, 11, 15-18, a10 (Andreev, 2002).

PARMELIOPSIS HYPEROPTA (Ach.) Arnold - on bark of Pinus sylvestris; 16-18.

Peltigera CANina (L.) Willd. - on mosses and soil; $\mathrm{m} 11, \mathrm{~m} 14, \mathrm{a} 6, \mathrm{a} 23$ (BG, H, LE; Andreev, 2002).

Peltigera didactyla (With.) J. R. Laundon - on bark of Alnus glutinosa, soil; a26. Collected from Tuters (no exact locality) by Balashova, 1993 (LECB; Alexeeva, 2005).

Peltigera extenuata (Nyl. ex Vain.) Lojka - on soil; a6 (LE).

Peltigera malacea (Ach.) Funck - on soil and mosses; a6. Collected from Tuters (no exact locality) by Brenner, 24.07.1868 (H 8000595; Brenner, 1886) and Balashova, 1993 (LECB; Alexeeva, 2005).

Peltigera polydactylon (Neck.) Hoffm. - on soil and mosses over rock; a47 (LE). Reported from Tuters (no exact locality) by Brenner (1886), as P. polydactyla (Neck.) Hoffm. f. collina Ach. This combination could be a synonym of $P$. collina (Ach.) Schrad., but this species is extremely rare in the Leningrad Region, and any material from Tuters is absent in herbaria. At the same time, the only specimen collected by Brenner from the Baltic islands and determined as $P$. polydactyla f. collina (H-NYL 33132, Hogland) refer to $P$. polydactylon - and we suppose Brenner's record from Tuters to be similar.

Peltigera PRAETEXTata (Flörke ex Sommerf.) Zopf - on soil; m2 (BG, LE; Andreev, 2002).

Peltigera Rufescens (Weiss) Humb. - on soil; a6. Collected from Tuters (no exact locality) by Balashova, 1993 (LECB; Alexeeva, 2005).

Pertusaria Amara (Ach.) Nyl. - on bark of Alnus glutinosa; a26 $(\mathrm{H})$.

Pertusaria Pertusa (Weigel) Tuck. - on bark of Alnus glutinosa; a26 (H). Specialized spe- cies of biologically valuable forests in the Southern Taiga of North-Western European Russia (Andersson et al., 2009).

PERTUSARIA PUPILlaris (Nyl.) Th. Fr. - on bark of Alnus glutinosa and Sorbus aucuparia; 14, 15. $19(\mathrm{H}, \mathrm{LE})$. Thalli contain fumarprotocetraric acid.

PHAEOPHYSCIA ORBICULARIS (Neck.) Moberg - on bark of Populus tremula; 2.

PhAEOPHYSCIA SCIASTRA (Ach.) Moberg - on concrete and on granite boulders; $\mathrm{m} 1, \mathrm{~m} 12,1$, a52 (Andreev, 2002).

Phlyctis ARGENa (Spreng.) Flot. - on bark of Alnus glutinosa, Picea abies, Populus tremula, Salix caprea and Sorbus aucuparia; m4, 2, 11, 15, 19, a21, a26 (BG, LE; Andreev, 2002).

Physcia adscendens (Fr.) H. Olivier - on bark of Populus tremula and on siliceous rocks; 2. Collected from Tuters (no exact locality) by Balashova, 1993 (LECB; Alexeeva, 2005).

Physcia AIPOlia (Ehrh. ex Humb.) Fürnr. - on bark of Pinus sylvestris and Populus tremula; 2,12 .

Physcia CAesia (Hoffm.) Fürnr. - on concrete and on siliceous rocks; 1, 3, 8, a52 (LE).

Physcia DUBIA (Hoffm.) Lettau - on bark of Pinus sylvestris and Quercus robur, on siliceous rocks; $\mathrm{m} 3, \mathrm{~m} 5, \mathrm{~m} 9, \mathrm{~m} 11,2-4,13$ (BG, LE; UPS L-116052; Andreev, 2002).

PHYSCIA STELLARIS (L.) Nyl. - on bark of Fraxinus excelsior and Quercus robur, m4, m11 (UPS L-116085; Andreev, 2002).

Physcia TENELla (Scop.) DC. - on bark of Alnus glutinosa, Populus tremula and Quercus robur, on siliceous rocks; $\mathrm{m} 5, \mathrm{~m} 11,1,2,4$, 8, 15 (BG, LE; UPS L-116088, L-116027; Andreev, 2002).

Physconia enteroxantha (Nyl.) Poelt - on bark of Populus tremula; a36.

Placynthiella Dasaea (Stirt.) Tønsberg - on lignum, plant debris and soil; 6, 7, 16, 18, a7, a23 (LE).

Placynthiella icmalea (Ach.) Coppins \& P. James - on bark and lignum of Pinus sylvestris, on plant debris, soil and upturned roots; 6, 7, 10, 11, 16-18, a7, a37 (H).

Placynthiella Oligotropha (J. R. Laundon) Coppins \& P. James - on plant debris, soil and sand; 5-7, 10, 12, a16, a25 (H, LE).

Placynthiella Uliginosa (Schrad.) Coppins \& P. James - on plant debris, soil and upturned roots; $7,11,12(\mathrm{H})$.

Platismatia glauca (L.) W. L. Culb. \& C. F. Culb. - on bark and lignum of Picea abies and 
Pinus sylvestris; m2, m7, m8, 6, 7, 11, 14 (BG, LE; Andreev, 2002).

\#Plectocarpon cf. ENCAUSTICUM (Nyl.) R. Sant. - on thallus of Brodoa intestiniformis on siliceous rock; a37 (BILAS). New to the North-Western European Russia. In Russia the species is known from Ural (Ertz et al., 2005). Distribution in Fennoscandia: Norway, Sweden (Nordin et al., 2011); not recorded in Baltic countries. This would be first record of the species for North-Western European Russia, however the specimen was not fully developed so we present it here with some doubt. The fungus induced basally constricted galls (to $0.8 \mathrm{~mm}$ diam.) with thalline pseudo-margin. Stromatic tissue brown, $\mathrm{K}^{+}$ olivaceous, $\mathrm{N}+$ reddish, no $\mathrm{K}+$ bright orange reaction noted, as described by Ertz et al. (2005). Fertile loculi few, spores not developed, conidia not seen.

Polycauliona CANDElaria (L.) Frödén et al. - on lignum of Pinus sylvestris and on siliceous rocks; m9, 1, 6, a11 (H; Andreev, 2002).

PolyCAUliona POLYCARPa (Hoffm.) Frödén et al. on bark of Alnus glutinosa, Alnus sp., Betula sp., Pinus sylvestris, Quercus robur and Salix sp., on lignum ( $\mathrm{m} 4, \mathrm{~m} 8, \mathrm{~m} 11,4-6,12,15$, a29 (UPS L-116036; Andreev, 2002).

\#Polycoccum PUlvinatum (Eitner) R. Sant. - on thallus of Physcia caesia on granite boulder; $1(\mathrm{H})$.

PoRPIDIA CinEREOATRA (Ach.) Hertel \& Knoph - on siliceous rocks and brick; 18, a6, 39 (LE).

PorPidia CRUSTUlata (Ach.) Hertel \& Knoph - on concrete and siliceous rocks; $\mathrm{m} 9, \mathrm{a} 6, \mathrm{a} 30$, a39 (UPS L-116042; Andreev, 2002).

PorPidia FLAVICUNDA (Ach.) Gowan - on siliceous rocks; m2 (Andreev, 2002).

Porpidia soredizodes (Lamy ex Nyl.) J. R. Laundon - on siliceous rocks; $4(\mathrm{H})$.

Porpidia tuberculosa (Sm.) Hertel \& Knoph - on siliceous rocks; $15(\mathrm{H})$.

PRotoparmelia Badia (Hoffm.) Hafellner - on siliceous rocks; m9, 12 (H, UPS L-116040; Andreev, 2002).

Protothelenella sphinctrinoidella (Nyl.) H. Mayrhofer \& Poelt - on dead mosses and cyanobacterial films; a38 (H).

PseudeVERnia FURfuracea (L.) Zopf - on bark of Picea abies, Pinus sylvestris and Salix sp., on lignum and siliceous rocks; m6-9, 5-8, 10-12, 14, 17, 18, a29, a46 (BG, LE, UPS L-116035; Andreev, 2002).
Pseudosagedia Aenea (Wallr.) Hafellner \& Kalb on bark of Picea abies, Salix caprea, Sorbus aucuparia; 11, 14, a23 (H).

Pseudosagedia Chlorotica (Ach.) Hafellner $\&$ Kalb - on siliceous rocks; 4, a23 $(\mathrm{H})$.

Pseudoschismatomma Rufescens (Pers.) Ertz \& Tehler - on bark of Alnus glutinosa, Populus tremula; 2, 19, a26 (H).

Psilolechia LUCIDA (Ach.) M. Choisy - on siliceous rocks; a37 (LE).

Pycnora PRAEstabilis (Nyl.) Hafellner - on lignum of Pinus sylvestris; a31 (H).

PYCNORA SOROPHORA (Vain.) Hafellner - on bark of Juniperus communis, Picea abies and Pinus sylvestris, on lignum of Pinus sylvestris; 6, 7, $11,17,18$, a31, a46 (H, LE). Thalli contain alectorialic acid.

RAMAlina FARINACEA (L.) Ach. - on bark of Alnus glutinosa, Populus tremula and Quercus robur, m4, 1, 2, 15 (H; Andreev, 2002).

RAMALINA FRAXINEA (L.) Ach. - on bark of Quercus robur, m11 (LE, sub Ramalina pollinaria det. O. A. Kataeva).

RAMALINA POLLINARIA (Westr.) Ach. - on bark of Alnus glutinosa and Quercus robur, m4, m11 (BG, LE; Andreev, 2002).

RAMALINA SILIQUOSA (Huds.) A. L. Sm. - not found in 1994-2015. Collected from Tuters (siliceous rocks, no exact locality) by Brenner, 24.07.1968 [H 8003430, 8003431; Brenner 1886, as Ramalina cuspidata (Ach.) Nyl., $R$. scopulorum auct. p. p.].

RAMALINA SUBFARINACEA (Nyl. ex Cromb.) Nyl. - on siliceous rocks; 8, a41, a42, a48 (H).

RHIZOCARPON CINEREOVIRENS (Müll. Arg.) Vain. - on siliceous rocks; a48 $(\mathrm{H})$.

RHIZOCARPON DISTINCTUM Th. Fr. - on siliceous rocks; m12 (UPS L-116095; Andreev, 2002).

RhizOCARPON EUPETRAEUm (Nyl.) Arnold - on siliceous rocks; a12 (BILAS, sub Arctoparmelia centrifuga).

RHIZOCARPON GEOGRAPHICUM (L.) DC. - on siliceous rocks; $\mathrm{m} 3, \mathrm{~m} 6,7,12$, a41, a43 (BG, $\mathrm{H}, \mathrm{LE}$, UPS L-116070; Andreev, 2002).

RHIZOCARPON HOCHSTETTERI (Körb.) Vain. - on siliceous rocks; a30 $(\mathrm{H})$.

RHIZOCARPON LECANORINUM Anders - on siliceous rocks; $\mathrm{m} 6, \mathrm{~m} 9, \mathrm{~m} 11,7$, a9, a12, a41 (BG, LE, UPS L-116068; Andreev, 2002).

RhizocARPon PETRAEum (Wulfen) A. Massal. - on brick; a6 (LE).

RHIZOCARPON POLYCARPUM (Hepp) Th. Fr. - on brick; a6 (LE). 
RHIZOCARPON REDUCTUM Th. Fr. - on siliceous rocks; a39 (LE).

RHIZOCARPON RICHARDII (Lamy ex Nyl.) Zahlbr. on siliceous rocks; $\mathrm{m} 1, \mathrm{~m} 5, \mathrm{~m} 10,3,8,13$, a48 (BG, H, LE, UPS L-116024, L-116063; Andreev, 2002).

Rimularia FURVElla (Nyl. ex Mudd) Hertel \& Rambold - on siliceous rocks and saxicolous lichens; $12(\mathrm{H})$.

RINODINA GENNARII Bagl. - on brick, concrete and siliceous rocks, once on lignum of Pinus sylvestris; m12, 3, 6, 13, a6 (H, UPS L-116094; Andreev, 2002).

RiNODINA PYRINA (Ach.) Arnold - on bark of Quercus robur and on iron; m11, 3 (LE; Andreev, 2002).

RiNODinA SOPHODEs (Ach.) A. Massal. - on bark of Sorbus aucuparia; m4 (LE; Andreev, 2002).

RoPALOSPORA VIRIDIS (Tønsberg) Tønsberg - on bark of Alnus glutinosa and Sorbus aucuparia; 11, 15, 19, a26 (H).

\#Roselliniella cladoniae (Anzi) Matzer \& Hafellner - on thallus of Cladonia arbuscula subsp. mitis on soil;18 (BILAS). New to North-Western European Russia. The nearest locality in European Russia is in Murmansk region (Zhurbenko \& Alstrup, 2004). Distribution in Fennoscandia and Baltic countries: Sweden (Nordin et al., 2011), Estonia (Randlane et al., 2016), Lithuania (Motiejūnaitè et al., 2003). Of all perithecioid fungi occurring on Cladonia, Roselliniella cladoniae is distinguished by dark brown (at maturity) simple to 1-4-septate (0-1-septate in our specimens) ascospores of varying shape, 2-8-spored asci and immersed to sessile ovoid perithecia with rough wall and free hyphae when mature (Zhurbenko \& Alstrup, 2004).

\#ROSELLINIELLA STEREOCAULORUM Zhurb., Kukwa \& Oset - on thallus of Stereocaulon cf. glareosum on soil; 5 . New to European Russia. The species is known in Europe from Poland, in Russia from Baikal Siberia and Yakutiya (Oset, 2014; Zhurbenko, 2010), but is not recorded in Fennoscandia and Baltic countries. The fungus is characterised by consistently 4-spored asci (when mature), simple ascospores with distinct apical nodules and the host choice - genus Stereocaulon (Zhurbenko et al., 2009; Zhurbenko, 2010).

SARCogyne hypophaEoides Vain. ex H. Magn. on siliceous rocks; $7(\mathrm{H})$. New to Russia.
Distribution in Fennoscandia: Norway, Sweden, Finland (Westberg et al., 2015); not recorded in Baltic countries. Crustose saxicolous lichen with immersed thallus, apothecia $0.5-1.2 \mathrm{~mm}$ wide, with reddishbrown to black disc, sometimes carbonized in central part. Can be distinguished from similar species - S. clavus (DC.) Kremp. and S. hypophaea (Nyl.) Arnold - by dark, brownish black to black hypothecium. S. hypophaeoides grows exclusively on siliceous rocks (Westberg et al., 2015).

+ SAREA RESinAe (Fr.: Fr.) Kuntze - on resin of Picea abies; $14(\mathrm{H})$.

SCHAERERIA FUSCOCINEREA (Nyl.) Clauzade \& $\mathrm{Cl}$. Roux - on siliceous rocks; m5, m6, m10, 7, a48 (BG, H, LE, UPS L-116022, L-116065; Andreev, 2002).

Scoliciosporum CHLOROCOCCUM (Graewe ex Stenh.) Vězda - on bark of Alnus glutinosa, Betula sp., Picea abies, Pinus sylvestris, Populus tremula and Quercus robur, on lignum of Pinus sylvestris; m4, 1, 2, 4-7, 11, 12, 15, a29 (H; Andreev, 2002).

SCOLICIOSPORUM SAROTHAMNI (Vain.) Vězda - on bark of Betula sp., Juniperus communis, Picea abies, Pinus sylvestris, Quercus robur, Salix sp. and Sorbus aucuparia, on lignum of Pinus sylvestris; 1, 5-7, 10-12, 17, 18, a29 (LE).

SCOLICIOSPORUm Umbrinum (Ach.) Arnold - on iron and siliceous rocks; $\mathrm{m} 3, \mathrm{~m} 5, \mathrm{~m} 10,4,13$, 18 (BG, H, LE, UPS L-116046, L-116064; Andreev, 2002).

\#SPhaEREllothecium PROPINQUellum (Nyl.) Cl. Roux \& Triebel - on apothecia of Lecanora carpinea on bark of Populus tremula; 1, 2 (BILAS).

SphaERophorus fragilis (L.) Pers. - on soil; 10 (LE).

SPHAEROPHORUS GLOBOSUS (Huds.) Vain. - not found in 1994-2015. Collected from Tuters (soil, no exact locality) by Brenner, 24.07.1968 (H 8003523).

STEREOCAULON ALPINUM Laurer - on soil; m15, 5, 9, 12, a3 (H). Collected from Tuters (no exact locality) by Brenner, 25.07.1868 (H s. n., as S. alpinum Laurer var. gracilentum Th. Fr.; H 8003531).

Stereocaulon Glareosum (L. I. Savicz) H. Magn. - on sand; 5, 6, 10, 12, a16 (H).

STEREOCAUlON InCRUSTATUM Flörke - on sand; m8, 5, 9 (H, UPS L-116060; Andreev, 2002). 
Stereocaulon nanodes Tuck. - on iron; a32 (H). New to LR. Distribution in North-Western European Russia outside LR and SPb: Republic of Karelia (Fadeeva et al., 2007). Distribution in Fennoscandia: Norway, Sweden, Finland (Nordin et al., 2011); not recorded in Baltic countries. Can be recognized due to the persistent, ascending to erect fanshaped phyllocladia with soredia on lower surface. Pseudopodetia are to $1 \mathrm{~cm}$ tall, sparingly branched, the branches flattened, sorediate below (Oset, 2014).

STEREOCAULON RIVULORUM H. Magn. - on sand; m8 (UPS L-116030; Andreev, 2002).

Stereocaulon saXatile H. Magn. - on iron, siliceous rocks and sand; m9, a32, a37 (BG, H, LE; Andreev, 2002).

Stereocaulon tomentosum Fr. - on sand; m9 (UPS L-116037; Andreev, 2002). Reported from Tuters (no exact locality) by Brenner (1886).

STRANGOSPORA MORIFORMIS (Ach.) Stein - on lignum of Pinus sylvestris; 6, a31 (H).

\#SYZYGOSPORA PHYSCIACEARUM Diederich - on thallus of Physcia sp. on granite boulder; 4 (BILAS).

TEPHROMELA ATRA (Huds.) Hafellner - on siliceous rocks, brick and lignum; $\mathrm{m} 1, \mathrm{~m} 5, \mathrm{~m} 9, \mathrm{~m} 10$, 8, 13, a6, a10, a43, a48 (BG, H, LE, UPS L-116062; Andreev, 2002).

Trapeliopsis flexuosa (Fr.) Coppins \& P. James - on bark and lignum of Pinus sylvestris; 6, 7, 16-18, a31 $(\mathrm{H})$.

TRAPELIOPSIS GRANUlOSA (Hoffm.) Lumbsch - on soil; 7, 10.

\#TREmella Lichenicola Diederich - on thallus of Violella fucata on bark of Pinus sylvestris; 11, 17 (LE).

Tremolecia atrata (Ach.) Hertel - on siliceous rocks; m3, m9 (UPS L-116073; Andreev, 2002).

TuCKERMANNOPSIS CHLOROPHYLLA (Willd. ex Humb.) Hale - on bark of Picea abies and lignum of Pinus sylvestris; m7, 6, 11, 14, $18(\mathrm{H}$; Andreev, 2002).

UMBILICARIA DEUsta (L.) Baumg. - on siliceous rocks; $\mathrm{m} 9,7,8,12,15$, a38, a41 $(\mathrm{H}$; Andreev, 2002).

UMBILICARIA HYPERBOREA (Ach.) Hoffm. - on siliceous rocks; m2, a37, a38 (BG, H, LE; Andreev, 2002). Red Data Book of LR (Tzvelev, 2000).
UMBILICARIA POLYPHYLLA (L.) Baumg. - on siliceous rocks; m9, 7, 12, a40, a41, a43 (H; Andreev, 2002).

UMBILICARIA POLYRRHIZA (L.) Fr. - on siliceous rocks; a38, a40 $(\mathrm{H})$. Red Data Book of LR (Tzvelev, 2000).

UMBILICARIA TORREFACTA (Lightf.) Schrad. - on siliceous rocks; $\mathrm{m9}, 7,12$, a41, a43, a48 (BG, H, LE; UPS L-116051; Andreev, 2002).

UsNeA HIRTA (L.) F. H. Wigg. - on lignum of Pinus sylvestris; $6(\mathrm{H})$.

VERRUCARIA MURALIS Ach. - on concrete; a6 (LE). Violella fuCATA (Stirt.) T. Sprib. - on bark and lignum of Pinus sylvestris; 11, 17 (LE). Thalli contain atranorin and fumarprotocetraric acid.

VULPICIDA PINASTRI (Scop.) J.-E. Mattsson \& M. J. Lai - on bark of Picea abies, Pinus sylvestris and Vaccinium myrtillus; 7, 11, 18, a29.

Xanthomendoza fulva (Hoffm.) Søchting et al. on lignum of Pinus sylvestris; 6 (LE).

XANTHOPARMELIA CONSPERSA (Ehrh. ex Ach.) Hale on siliceous rocks, soil and sand; $\mathrm{m} 9,4,7$, 8, 12, 15, a41 (BG, H, LE; UPS L-116048; Andreev, 2002).

XANTHOPARMELIA PUlLA (Ach.) O. Blanco et al. - on siliceous rocks; $\mathrm{m} 3, \mathrm{~m} 5, \mathrm{~m} 6, \mathrm{~m} 9,3,8,12$, 13 (H; Andreev, 2002). Red Data Book of LR (Tzvelev, 2000).

Xanthoparmelia stenophylla (Ach.) Ahti \& D. Hawksw. - on siliceous rocks, soil; m9, 12 (H, UPS L-116047; Andreev, 2002).

XANTHOPARMELIA VERRUCULIFERA (Nyl.) O. Blanco et al. - on siliceous rocks; m5 (Andreev, 2002).

XANTHORIA AUREOla (Ach.) Erichsen - on siliceous rocks; m5 (UPS L-116020; Andreev, 2002).

XANTHORIA PARIETINA (L.) Th. Fr. - on bark of Padus avium, Populus tremula and Quercus robur, on brick, concrete, iron, siliceous rocks and once on soil; $\mathrm{m} 11,1-3,8,13,19, \mathrm{a} 6, \mathrm{a} 52$ (BG, LE; Andreev, 2002).

XylograPha OPEGRAPHELla Nyl. ex Rothr. - on lignum; a10, a19 (H).

Xylopsora CARAdocensis (Nyl.) Bendiksby \& Timdal - on lignum of Pinus sylvestris; 6, a31 $(\mathrm{H})$.

XYlopsora FRIESII (Ach.) Bendiksby \& Timdal - on bark of Pinus sylvestris; 16 (LE).

\section{Excluded taxa}

Cladonia Portentosa (Dufour) Coem. (Andreev, 2002; Alexeeva, 2005). The specimen belongs to C. arbuscula subsp. mitis. 
Cetraria odontella (Ach.) Ach. (Brenner, 1886). The specimen belongs to $C$. muricata.

LECANORA PERSIMILIS (Th. Fr.) Nyl. (Andreev, 2002; Alexeeva, 2005). The specimen belongs to M. hagenii.

LEPRARIA CAESIOALBA (B. de Lesd.) J. R. Laundon (Andreev, 2002). The specimen belongs to L. jackii.

Physcia leptalea (Ach.) DC. (Andreev, 2002; Alexeeva, 2005). The specimen is too small for the convinced identification, similar to P. stellaris.

\section{DISCUSSION}

The currently known lichen biota of Tuters comprises altogether 331 species, including 314 lichenized, 16 lichenicolous and one nonlichenized saprobic fungi. Of them, Aspicilia epiglypta, Fuscidea praeruptorum, Micarea byssacea and Sarcogyne hypophaeoides are reported for the first time for Russia, Roselliniella stereocaulorum - for European Russia, Aspicilia polychroma, Carbonea vorticosa, Cercidospora stereocaulorum, Cladonia ciliata f. flavicans, C. rangiformis, Parmelia ernstiae, Plectocarpon cf. encausticum and Roselliniella cladoniae - for North-Western European Russia; Bachmanniomyces uncialicola, Bacidina sulphurella, Micarea botryoides, Miriquidica griseoatra and Stereocaulon nanodes are new to the Leningrad Region. Altogether 202 species are new for the Tuters Island.

Almost all the listed species are present on Tuters Island nowadays (recorded since 1992), two species were collected by Brenner only: $R a-$ malina siliquosa and Sphaerophorus globosus. Both are known in Leningrad Region also from Hogland Island (Brenner, 1886), but all records are from 19th century. The species might have disappeared during the war: the strongest artillery batteries were situated along the shoreline, so the surface of the rocks could be damaged.

The majority of 329 species recorded nowadays on Tuters Island inhabit bark of trees and shrubs (133 species, 40\% of lichen biota) and siliceous rocks (113 species, 34\%); rather diverse are lichens also on lignum (74 species, $23 \%$ ) and soil (71 species, 22\%). Among phorophytes, the richest in species are pine (57 lichen species), spruce (47 species), black alder (41 species) and aspen (29 species). Lignicolous lichens were found both on natural wood (51 species) and on transformed substrata - timber of old war constructions (36 species) and driftwood (11 species, including some normally saxicolous lichens, such as Parmelia saxatilis and Tephromela atra).

Most diverse are lichens in rocky landscapes: 158 species ( $48 \%$ of lichen biota) were recorded on rocky seashores and granite ridges in the western and northwestern parts of the island. Many species distributed along Tuters seashores are rare or not recorded in other parts of the Leningrad Region. For example, coastal foliose lichen Anaptychia runcinata was earlier known in LR only from Hogland Island ( $\mathrm{H}$, collected up to 1939); saxicolous crustose lichens Aspicilia epiglypta, Fuscidea praeruptorum and Sarcogyne hypophaeoides are recorded for the first time for Russia. Lichens of the dune area (eastern part of the island) are represented by 124 species (38\% of lichen biota). Cladonia ciliata f. flavicans finding on Tuters is the easternmost locality of this species in Europe. Calicium tigillare was found on old timber fence on dune; this species became rare in NW European Russia and now deserves protection. Lichens in abandoned village and other anthropogenic landscapes are also diverse (105 species, 32\%), as well as seashores with big boulders (105 species, 32\%). Of special interest are lichens of spruce forests situated in the northern part of Tuters. Altogether 72 species $(22 \%)$ of lichens and allied fungi were found in relatively old-growth spruce stands; among them, Arthonia spadicea, Chaenotheca stemonea, Felipes leucopellaeus, Lecanactis abietina are indicator or specialized species of biologically valuable forests in Southern Taiga of North-Western European Russia (Andersson et al., 2009). The lichens in other natural communities of Tuters Island (pine forests outside rocks and dunes, black alder stands, bogs etc.) are in general not so diverse and specific.

Altogether eleven species known from Tuters Island are included in the Red Data Book of Nature of the Leningrad Region (Tsvelev, 2000): Arctoparmelia centrifuga, A. incurva, Brodoa intestiniformis, Cetrariella commixta, Cladonia macrophylla, Melanelia hepatizon, M. stygia, Ramalina fraxinea, Umbilicaria hyperborea, U. polyrrhiza, Xanthoparmelia pulla, most of them are saxicolous and confined to the rocky outcrops. Additionally, 9 species are recommended to be included into the new edition of the Red Data Book of Leningrad Region: Acrocordia cavata, 
Arthonia spadicea, Calicium tigillare, Cladonia scabriuscula, Felipes leucopellaeus, Lasallia pustulata, Lecanactis abietina, Pertusaria pertusa, Sphaerophorus fragilis.

To sum up, on Tuters Island rich and diverse lichen biota is relatively well-preserved, and it is worthy to be protected.

\section{ACKNOWLEDGEMENTS}

We would like to thank Russian Geographical Society for organization of field trip in 2015. We are grateful to our colleagues from Komarov Botanical Institute RAS (St. Petersburg): Julia V. Gerasimova for identification of Bacidina sulphurella, Olga A. Kataeva for revision of Ramalina specimens as well as Sergey V. Chesnokov and H. J. M. Sipman for help in TLC for Micarea specimens. The first author thanks Elena A. Glazkova (Komarov Botanical Institute RAS) for great help during field investigations. We are grateful to our colleagues at the Komarov Botanical Institute, Botanical Museum of University of Helsinki, Museum of Evolution of Uppsala University and Bergen University for the support of our investigations in herbaria of LE, H, UPS and BG. Authors would like to thank an anonymous reviewer and Tiina Randlane for valuable corrections and comments. The study was financially supported by the Russian Geographical Society (field investigations in 2015) and Russian Foundation for Basic Research (grant 16-04-01488), research partly was carried out within the framework of the institutional research project (no. 01201255601) of the Komarov Botanical Institute RAS.

\section{REFERENCES}

Ahti, T. \& Stenroos, S. 2013. Cladonia. In: T. Ahti, S. Stenroos \& R. Moberg (eds). Nordic Lichen Flora. Volume 5. Cladoniaceae. Uddevalla, pp. 8-86.

Alexeeva, N. M. 2005. Lichens from islands in the Russian part of the Gulf of Finland. Folia Cryptogamica Estonica 41: 5-12.

Andersson, L., Alexeeva, N. \& Kuznetsova, E. (eds). 2009. Survey of biologically valuable forests in North-Western European Russia. Vol. 2. Identification manual of species to be used during survey at stand level. St. Petersburg. 258 pp. (in Russian).

Andreev, M. P. 2002. Lichens of Bolshoi Tyuters island in Gulf of Finland, Leningrad Region. Novitates Systematicae Plantarum Non Vascularum 36: 73-79. (in Russian, English summary).
Andreev, M., Kotlov, Yu. \& Makarova, I. 1996. Checklist of Lichens and Lichenicolous Fungi of the Russian Arctic. Bryologist 99(2): 137-169. https:// doi.org/10.2307/3244545

Brand, M., Coppins, B. J., van den Boom, P. P. G. \& Sérusiaux, E. 2009. Further data on the lichen genus Bacidia s. 1. in the Canary Islands and Western Europe, with descriptions of two new species. Bibliotheca Lichenologica 99: 81-92.

Brenner, M. 1886. Bidrag till kannedom af Finska vikens ovegetation. IV. Hoglands lafvar. Meddelanden af Societas pro Fauna et Flora Fennica 13: 1-144.

Chambers, S. P., Galloway, D. J. \& James, P. W. 2009. Carbonea (Hertel) Hertel (1983). In: Smith, C. W., Aptroot, A., Coppins, B. J., Fletcher, A., Gilbert, O. L., James, P. W. \& Wolseley, P. A. (eds). The lichens of Great Britain and Ireland. London, pp. 278-280.

Coppins, B. J. 1983. A taxonomic study of the lichen genus Micarea in Europe. Bulletin of the British Museum (Natural History), Botany series 11: $17-214$

Czarnota, P. \& Guzow-Krzemińska, B. 2010. A phylogenetic study of the Micarea prasina group shows that Micarea micrococca includes three distinct lineages. Lichenologist 42(1): 7-21. https://doi. org/ 10.1017/S0024282909990211

Czarnota, P. 2007. The lichen genus Micarea (Lecanorales, Ascomycota) in Poland. Polish Botanical Studies 23: 1-199.

Dedkov, V. P., Andreev, M. P. \& Petrenko, D. E. 2007. Annotated list of lichens of Kaliningrad Region. Biodiversity of Kaliningrad Region. Part 1. Fungi, lichens, club-mosses, horsetails and ferns of Kaliningrad Region. Kaliningrad, pp. 79-178. (In Russian).

Ertz, D., Christnach, C., Wedin, M. \& Diederich, P. 2005. A world monograph of the genus Plectocarpon (Roccellaceae, Arthoniales). Bibliotheca Lichenologica 91: 1-155.

Fadeeva, M. A., Golubkova, N. S., Vitikainen, O. \& Ahti, T. 2007. Conspectus of lichens and lichenicolous fungi of the Republic of Karelia. Petrozavodsk. 194 pp. (In Russian, English summary).

Fletcher, A., Purvis, O. W. \& Coppins, B. J. 2009. Aspicilia A. Massal. (1852). In: Smith, C. W., Aptroot, A., Coppins, B. J., Fletcher, A., Gilbert, O. L., James, P. W. \& Wolseley, P. A. (eds). The lichens of Great Britain and Ireland. London, pp. 181-188.

Giavarini, V., Coppins, B. J. \& Purvis, O. W. 2009. Miriquidica Hertel \& Rambold (1987). In: Smith, C. W., Aptroot, A., Coppins, B. J., Fletcher, A., Gilbert, O. L., James, P. W. \& Wolseley, P. A. (eds). The lichens of Great Britain and Ireland. London, pp. 607-611.

Gilbert, O. L., Purvis, O. W., Skjoldahl, L. H. \& Tønsberg, T. 2009. Fuscidea V. Wirth \& Vězda (1972). In: Smith, C. W., Aptroot, A., Coppins, B. J., Fletcher, A., Gilbert, O. L., James, P. W. \& 
Wolseley, P. A. (eds). The lichens of Great Britain and Ireland. London, pp. 407-411.

Glazkova E. A. 2001. Vascular flora of the islands of the eastern GuIf of Finland: structure and analysis. St. Petersburg. 348 pp. (In Russian).

Hakulinen, R. 1962. Die Flechtengattung Anaptychia Körb. in Ostfennoskandien. Archivum Societatis Zoologicae Botanicae Fennicae Vanamo 17 (Not. 3): 121-133.

Hawksworth, D. L. 1981. The lichenicolous Coelomycetes. Bulletin of the British Museum (Natural History), Botany series 9: 1-98.

Himelbrant, D. E., Stepanchikova, I. S., Motiejūnaitè, J., Gerasimova, Ju. V., Kuznetsova, E. S., Dyomina, A. V. \& Tsurykau, A. G. 2017. New records of lichens and allied fungi from the Leningrad Region, Russia. VIII. Folia Cryptogamica Estonica 54: 63-70. https://doi.org/10.12697/fce.2017.54.11

Ihlen, P. G. \& Wedin, M. 2008. An annotated key to the lichenicolous Ascomycota (including mitosporic morphs) of Sweden. Nova Hedwigia 86: 275-365. https://doi.org/10.1127/00295035/2008/0086-0275

Motiejūnaitè, J. 1999. Checklist of lichens and allied fungi of Lithuania. Botanica Lithuanica 5(3): 251-269.

Motiejūnaitè, J. 2015. Lichens And Allied Fungi From The Čepkeliai State Nature Reserve (Southern Lithuania). Botanica Lithuanica 21(1): 3-12. https://doi.org/10.1515/botlit-2015-0001

Motiejūnaitė, J., Alstrup, V., Randlane, T., Himelbrant, D., Stončius, D., Hermansson, J., Urbanavichus, G., Suija, A., Fritz, Ö., Prigodina Lukošienè, I. \& Johansson, P. 2008. New or noteworthy lichens, lichenicolous and allied fungi from Biržai District, Lithuania. Botanica Lithuanica 14: 29-42.

Motiejūnaitè, J., Berglund, T., Czarnota, P., Himelbrant, D., Högnabba, F., Konoreva, L. A., Korchikov, E. S., Kubiak, D., Kukwa, M., Kuznetsova, E., Leppik, E., Lõhmus, P., Prigodina Lukošienè, I., Pykälä, J., Stončius, D., Stepanchikova, I., Suija, A., Thell, A., Tsurykau, A. \& Westberg M. 2012. Lichens, lichenicolous and allied fungi found in Asveja Regional park (Lithuania). Botanica Lithuanica 18(2): 85-100. https://doi.org/10.2478/ v10279-012-0011-9

Motiejūnaitė, J., Brackel, W. v., Stončius, D. \& Preikša, Ž. 2011. Contribution to the Lithuanian flora of lichens and allied fungi. III. Botanica Lithuanica 17(1): 39-46.

Motiejūnaitè, J., Kukwa, M., Czarnota, P., PrigodinaLukošienè, I., Himelbrant, D., Kuznetsova, E. \& Kowalewska, A. 2003. Lichens and allied fungi collected during the XV Symposium of Baltic Mycologists and Lichenologists in Birštonas, Lithuania. Botanica Lithuanica 9(2): 109-119.

Motiejūnaitè, J. \& Piterāns, A. 1998. Materials on lichens and allied fungi of Kemeri National Park (Latvia). Botanica Lithuanica 4(2): 187-196.
Nordin, A., Moberg, R., Tønsberg, T., Vitikainen, O., Dalsätt, Å., Myrdal, M., Snitting, D. \& Ekman, S. 2011. Santesson's Checklist of Fennoscandian Lichen-forming and Lichenicolous Fungi. Ver. April 29, 2011 http://130.238.83.220/santesson/ home.php (25 March 2017).

Orange, A. 2012. Semi-cryptic marine species of Hydropunctaria (Verrucariaceae, lichenized Ascomycota) from north-west Europe. Lichenologist 44(3): 299-320. https://doi.org/10.1017/ S0024282911000867

Orange, A., James, P. W. \& White, F. J. 2001. Microchemical methods for the identification of lichens. London. $101 \mathrm{pp}$.

Oset, M. 2014. The lichen genus Stereocaulon (Schreb.) Hoffm. in Poland - a taxonomic and ecological study. Monographiae Botanicae 104: 1-81. https: / / doi.org/10.5586/mb.2014.001

Piterāns, A. 2001. Latvijas k̦ērpju konspekts. Latvijas veǵetācija 3: 5-46. (In Latvian).

Printzen, C. \& Otte, V. 2005. Biatora longispora, new to Europe, and a revised key to European and Macaronesian Biatora-species. Graphis scripta 17: 56-61.

Randlane, T., Saag, A. \& Suija, A. 2016. Lichenized, lichenicolous and allied fungi of Estonia. Ver. December 31, 2016 - http://esamba.bo.bg.ut.ee/ checklist/est/home.php (25 March 2017).

Stepanchikova, I. S., Himelbrant, D. E., Dyomina, A. V. \& Tagirdzhanova, G. M. 2015. The lichens and allied fungi of the Zapadny Kotlin protected area and its vicinities (Saint Petersburg). Novitates Systematicae Plantarum Non Vascularum 49: 265-281.

Stepanchikova, I. S., Himelbrant, D. E., Kukwa, M. \& Kuznetsova, E. S. 2011. New records of lichens and allied fungi from the Leningrad Region, Russia II. Folia Cryptogamica Estonica 48: 85-94.

Thell, A., Thor, G. \& Ahti, T. 2011. Parmelia. In: A. Thell $\&$ R. Moberg (eds). Nordic Lichen Flora. Volume 4. Parmeliaceae. Uddevalla, pp. 83-90.

Tzvelev, N. N. (ed.). 2000. Red Data Book of Nature of the Leningrad Region. Vol. 2. Plants and Fungi. St. Petersburg. 672 pp. (In Russian).

Urbanavichus, G., Ahti, T. \& Urbanavichene, I. 2008. Catalogue of lichens and allied fungi of Murmansk Region, Russia. Norrlinia 17: 1-80.

Urbanavichus, G. P. \& Urbanavichene, I. N. 2008. Parmelioid, cetrarioid and hypogymnioid lichens (Parmeliaceae) of Russia: first check-list and distribution data. Novitates Systematicae Plantarum Non Vascularum 42: 198-218. (In Russian).

Westberg, M., Timdal, E., Asplund, J., Bendiksby, M., Haugan, R., Jonsson, F., Larsson, P., Odelvik, G., Wedin, M. \& Millanes, A. M. 2015. New records of lichenized and lichenicolous fungi in Scandinavia. MycoKeys 11: 13-61. https://doi.org/10.3897/ mycokeys. 11.6670

Wirth, V., Hauck, M. \& Schultz, M. 2013. Die Flechten Deutschlands. Band 1. 672 pp. 
Zhurbenko, M. P, Kukwa, M \& Oset, M. 2009. Roselliniella stereocaulorum (Sordariales, Ascomycota), a new lichenicolous fungus from the Holarctic. Mycotaxon 109(1): 323-328. https:// doi.org/ 10.5248/109.323

Zhurbenko, M. P. \& Alstrup, V. 2004. Lichenicolous fungi on Cladonia mainly from the Arctic. Symbolae Botanicae Upsalienses 34(1): 477-499.
Zhurbenko, M. P. 2010. Lichenicolous fungi and lichens growing on Stereocaulon from the Holarctic, with a key to the known species. Opuscula Philolichenum 8: 9-39. 